\title{
Herremænd på Haderslev Næs i middelalderen
}

\author{
Af Henrik Fangel
}

\section{Indledning}

I Sønderjyske Årbøger 1972 forsøgte jeg at vise, hvorledes omfattende arvedelinger og giftermål var skyld i en gradvis og efterhånden fuldstændig splittelse af et stort godskompleks. Det tilhørte slægten Emmiksen og synes omkr. 1475 at have omfattet ca. 140 fæstegårde. Splittelsen opfattede jeg som en væsentlig årsag til den tilbagegang, der kan konstateres for den sønderjyske herremandsstand i 14-1500-tallet, og til kronens erhvervelse af dette herremandsgods i slutningen af 1500-årene.

Af undersøgelsen fremgik det endvidere, at det godskompleks, der således splittedes, ikke var særligt gammelt, men først synes skabt $\mathrm{i}$ begyndelsen af 1400-årene, og jeg gav i afhandlingen nogle antydninger af, hvorledes det var skabt. På dette grundlag må det opfattes som et kompleks typisk for 1400-tallet. Nord for Kongeåen kan vi netop på denne tid konstatere eksistensen af sådanne omfattende godskomplekser. Vi er endog i mange tilfælde i stand til at følge deres tilblivelseshistorie, der viser store strukturelle ændringer inden for landbruget $\mathrm{i}$ slutningen af 1300 tallet og første halvdel af 1400-årene, især i form af koncentration af gods på få hænder.' Slægten Emmiksens godskompleks illustrerer en tilsvarende udvikling i hertugdømmet på samme tid.

Kendskabet til denne ændringsproces rejser spørgsmålet om, hvad der er gået forud, og specielt hvad der er årsag til ændringen. Rent logisk må ændringerne have betydet, at nogle mennesker har mistet eller opgivet deres gods. Da disse "nogle« nok stort set må tilhøre et lavere socialt lag inden for herremandsstanden, og da vi tidsmæssigt føres tilbage i 1300-tallet, rejser besvarelsen af disse spørgsmål imidlertid store kildemæssige problemer, i hvert fald når 
vi beskæftiger os med sønderjyske forhold: de skriftlige kilder mangler i vid udstrækning.

I det følgende skal der imidlertid inden for et begrænset område, Haderslev Næs, halvøen mellem Haderslev og Genner fjorde, forsøges kastet lys også over perioden før ca. 1400. Midlerne hertil er tre:

1) det skriftlige kildemateriale, der først for tiden efter 1400 er fyldestgørende;

2) den viden, de endnu idag bevarede eller kendte voldsteder på Haderslev Næs giver om, hvor herremænd må have været bosiddende;

3) den almene viden, som den historiske forskning efterhånden har erhvervet om krisetilstandene inden for landbruget i senmiddelalderen, en viden, der nødvendigvis må inddrages, når man skal forsøge at forklare ændringsprocesserne inden for landbruget i 13-1400-tallet.

En kombination af disse tre faktorer skulle gøre det muligt også at sige noget om tiden før 1400, hvor de ændringer stort set må have fundet sted, som vi ser resultatet af i 1400-tallet. I afhandlingen om slægten Emmiksen er det antydet, at også agrarkrisen sammen med de arvedelinger og giftermål, som er udførligt behandlet i afhandlingen, kan have spillet ind i forbindelse med den sønderjyske herremandsstands tilbagegang middelalderen igennem. Det er denne antydning, der her skal konkretiseres med udgangspunkt $\mathrm{i}$ voldstederne og det skriftlige kildemateriale overvejende fra tiden efter 1400.

\section{Voldsteder på Haderslev Nas}

Haderslev Næs er som hele det gamle Haderslev amt rigt på middelalderlige voldsteder, eller man bør måske snarere sige, at voldstederne her er arkæologisk lokaliseret og registreret, så at det måske i højere grad er arkæologernes aktivitet, der afspejles, end en for dette område speciel talrig forekomst af voldsteder. De i dag kendte og lokaliserede voldsteder er følgende ${ }^{2}$ : 


\section{Halk sogn:}

1) Bolet skov, lille rundagtig banke, ca. $8 \times 8 \mathrm{~m}$ stor, i sydvest afgrænset af en bæk, på de øvrige sider af en ca.2-2,5 m bred grav; lidt vest for dette anlæg en halvcirkelformet dæmning. Det omsluttede areal, der åbner sig mod bækken, har antagelig tjent som mølledam og måler øst-vest ca. $40 \mathrm{~m}$, nord-syd maksimalt $25 \mathrm{~m}$.

2) Henneskær ${ }^{3}$, en forhøjning i engene vest for Hejsager, hvortil flere veje fører ud, sløjfet.

3) Langmose, kun svage spor af voldgrave omkring gården; et stort vandhul, der skal have udgjort anlæggets sydside, er derimod endnu bevaret.

4) Holmhøje, rund hovedbanke med en aflang noget højere forborg i engene syd for Halk by.

5) Ultanggård, vandfyldte grave, heraf hele nordre grav, ca. $75 \mathrm{~m}$ lang, af vestre grav ca. 60 $\mathrm{m}$ og af østre grav ca. $45 \mathrm{~m}$ (ydre mål), 4-5 m brede.

\section{Starup sogn:}

6) Hussted banke, ca. $300 \mathrm{~m}$ VSV for Kobbelgaird i Lønt, en naturlig banke, ca. $50 \times 50 \mathrm{~m}$ stor, beliggende i et blødt engdrag uden spor af befæstning på eller ved banken, men der er fundet brolægning eller syld på dens top; i engen endvidere pæle fra et vejsystem, der formentlig har ført ud til banken fra det faste land ca. $40 \mathrm{~m}$ i nord. Banken har tidligere været omflydt af vand.

7) Vandlinggårds bygninger ligger på et fladt plateau, der synes at have været et ca. $70 \times 100$ $\mathrm{m}$ stort voldsted, hvoraf der er meget lidt at se nu. Voldstedets sydøsthjørne viser sig dog ved et ca. $2 \mathrm{~m}$ bredt og $1 \mathrm{~m}$ højt retvinklet voldstykke, der i syd er bevaret over en strækning af ca. $35 \mathrm{~m}$, i øst af ca. $40 \mathrm{~m}$.

\section{Vilstrup sogn:}

8) øst for Kingsgård i Kelstrup, rund banke ca. $25 \mathrm{~m}$ i diameter og ca. $4 \mathrm{~m}$ høj med stejle sider og en ca. $10 \times 10 \mathrm{~m}$ stor topflade samt grav omkring. Vest herfor i en afstand af ca. 9 $\mathrm{m}$ en oval banke med længderetning nord-syd, ca. $30 \times 15 \mathrm{~m}$ stor og $3 \mathrm{~m}$ høj.

9) Bodskov, af de formentlige voldgrave findes nu kun en ca. $12 \times 40 \mathrm{~m}$ stor og ca. $1-1,5 \mathrm{~m}$ dyb tør sænkning, orienteret tilnærmelsesvis NV-S $\emptyset$, beliggende $S \varnothing$ for stuehuset. Hvis det er en voldgrav, er det den østlige del af søndre grav, og den østre grav har da snarest ligget i marken umiddelbart øst for gårdens have, hvor der ses en svag sænkning.

10) Vonsmose, en ca. $120 \mathrm{~m}$ lang vandfyldt grav nord for gården, som i vest udvider sig og danner en kunstig sø, ca. 40-50 m stor, i hvilken der ligger en rundagtig banke med en diameter på ca. $20 \mathrm{~m}$. Dens topflade ligger ca. $2 \mathrm{~m}$ over vandspejlet i graven og ca. $1 \mathrm{~m}$ højere end det omgivende terræn.

Hoptrup sogn:

11) nord for Over Kestrup, et noget udjevnet firesidet voldsted i form af en høj banke, der skyder sig ud i en nu delvis opfyldt og drænet sø. Denne banke er ved en ca. $10 \mathrm{~m}$ bred voldgrav afskåret til en borgbanke, der endnu er ca. 1,5 $\mathrm{m}$ høj og har en udstrækning på ca. 25-30 m, men er stærkt afgravet især mod øst, hvor der er fundet og nedbrudt en kælder. Jorden indeholder teglstensbrokker og kalkmørtel.

Disse voldsteder er ikke på nogen måde undersøgt tilbundsgående arkæologisk og derfor heller ikke daterede særlig nøjagtigt. I det hele taget er vor viden om de middelalderlige voldsteder endnu ret 
ringe. Kun så meget kan siges, at der $\mathrm{i}$ hvert fald synes at kunne udskilles en yngre og en ældre gruppe; til den yngre hører de tydeligt firesidede anlæg med grave omsluttende en ret stor plads, her ca. $70-120 \mathrm{~m}$ på hver side. Det er den såkaldte "herregårdsplads«type, der har båret både beboelses- og avlsbygninger, og som på Næsset repræsenteres ved Langmose, Ultanggård, Bodskov og Vandlinggård. En anden og sikkert ældre gruppe er den, der er karakteriseret ved en lille, ofte cirkelrund banke med grave og evt. en forborg, hvor banken formodentlig har båret beboelses- eller blot tilflugtsbygninger, mens forborgen har båret avls- og måske også beboelsesbygninger. Den er repræsenteret ved Bolet, Holmhøje, Hussted banke, Kingsgård, Vonsmose, Over Kestrup og måske Henneskær. Af disse mangler $\mathrm{i}$ hvert fald Bolet, Hussted banke og Over Kestrup forborgen, men da de to sidstnæunte ligger på naturlige og ret store banker, kan avlsbygninger o. l. have ligget på selve banken eller evt. på det faste land. Voldstedet i Bolet skov er formodentlig det mindste af de her nævnte voldsteder, kun $8 \times 8$ $\mathrm{m}$ i diameter, og kan derfor næppe have rummet bygninger af større anvendelighed. Det er dog netop herved typisk, idet det viser, hvordan det fortifikatoriske var hovedsagen ved disse små runde voldsteder: på banken stod en sten- eller træbygning, der var sidste tilflugtsmulighed under belejring.

Arkæologien kan på nuværende tidspunkt næppe bringe os længere, og ser vi på den historiske viden om voldstederne, synes den særdeles ringe. Kun for den yngste gruppes vedkommende kender vi ejerne og det først i 1500-tallet; men selvom det er en yngre type, er i hvert fald nogle af dem dog nok ældre end 1500tallet. De øvriges ejerforhold er aldeles ukendt, måske bortset fra Bolet og Kestrup, som dog først nævnes i 1500-tallet.

Til trods for de meget begrænsede oplysninger, arkæologien giver os om disse voldsteder og deres alder, er de imidlertid et særdeles konkret udgangspunkt for en undersøgelse af, hvor vi skal søge herremændene inden for dette meget afgrænsede område. Spørgsmålet er nemlig, om det ikke ved kombination med det skriftlige kildemateriale $\mathrm{i}$ form af breve (diplomer) skulle være muligt at få $\mathrm{i}$ hvert fald nogle af disse voldsteder beboet og gjort levende som hjemsted for en række småherremænd. Vi træffer nemlig i første halvdel af 1400-tallet, da kildematerialet begynder at 
flyde rigeligere, en lang række småherremænd, der ganske klart hører hjemme på Næsset. Ved kombination af brevenes direkte og indirekte oplysninger om disse personer er det muligt at knytte en række af dem sammen i slægter samt at lokalisere, hvor deres gods var beliggende. Her ligger en mulighed for en tilknytning til voldstederne.

$\mathrm{Da}$ forfatteren til denne afhandling er historiker og ikke arkæolog, vil udgangspunktet $\mathrm{i}$ det følgende derfor ikke være voldstederne, men den række slægter og personer, som vi træffer i de middelalderlige breve. På grundlag heraf vil jeg om muligt forsøge at knytte hver enkelt af disse slægter eller personer sammen med voldstederne. Dette må imidlertid kun betragtes som et forsøg ud fra de historiske vidnesbyrd. De arkæologiske vil måske ved nærmere undersøgelse vise, at de pågældende voldsteder har en helt anden alder (eller måske slet ikke er voldsteder!) og derfor slet ikke kan knyttes til disse personer eller slægter.

Herremand på Haderslev Nas i begyndelsen af 1400-tallet Kildematerialet

Den katolske kirke med dens faste organisation har altid været kendetegnet ved en normalt velfungerende administration af bl. a. sine store ejendomsbesiddelser. Som følge heraf har den også forstået at holde orden på sine dokumenter, der bl.a. omfattede adkomstbreve for det gods, den ejede. Dette forhold har vi at takke for, at vi i det hele taget har nogensomhelst viden om herremænd på Haderslev Næs. Kollegiatkapitlet ved Vor Frue kirke i Haderslev erhvervede $\mathrm{i}$ tidens løb en del gods og ejede ved år $1500 \mathrm{ca} .80$ gårde $\mathrm{i}$ egnen omkring Haderslev. Hele kapitlets arkiv indeholdende bl. a. adkomstbreve på størstedelen af dette gods, fandtes endnu i 1598 i hertug Hans den Ældres arkiv og omfattede da 149 breve. ${ }^{4}$ Siden da er disse breve gået tabt, men en del kendes dog $i$ afskrift. Netop fra Haderslev Næs kendes på denne måde en del breve fra forste halvdel af 1400-tallet, da kapitlet erhvervede en del gods her, hovedsagelig fra herremænd. Vi får på denne måde kendskab til gods, der er gået ud af disse herremænds besiddelse, men da brevene ofte er bevidnet af andre herremænd, 


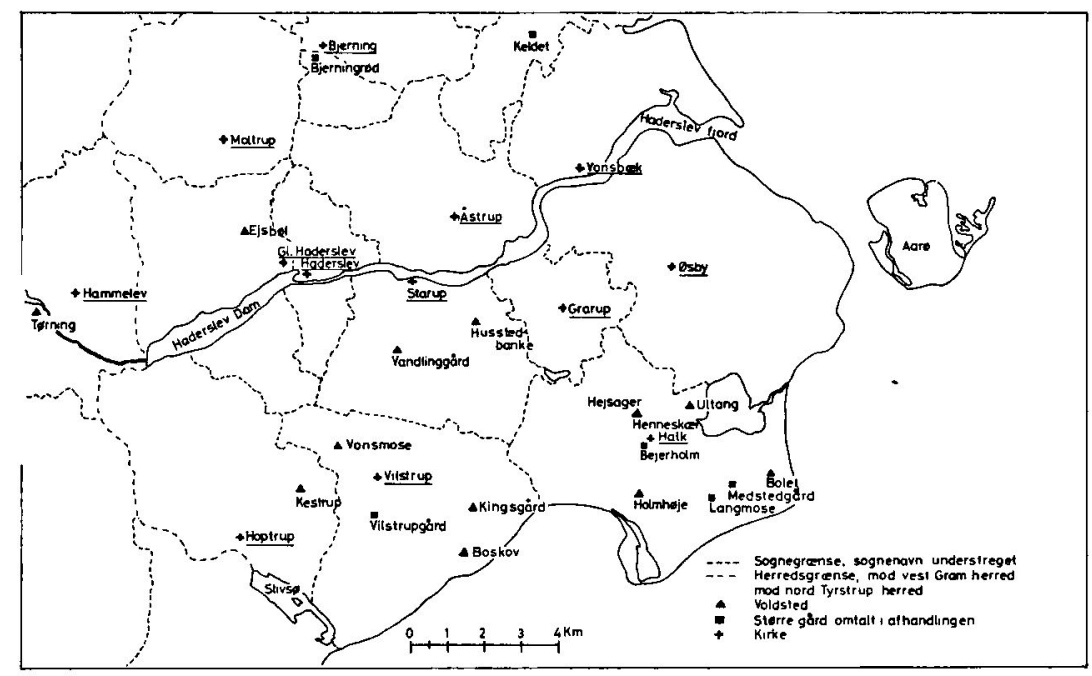

Kort over Haderslev Nas med de voldsteder og større gårde, der omtales $i$ artiklen.

giver de også indirekte oplysninger om, hvem der har været bosiddende på Næesset. ${ }^{5}$

På grundlag heraf skulle det være muligt at give et indtryk af, hvad der har været af herremænd på Næsset, generelt set i første halvdel af 1400-tallet, men i særdeleshed omkring år 1420, hvor materialet er særligt fyldigt. Det følgende vil derfor forme sig som en gennemgang af de slægter, vi finder i første halvdel af 1400-tallet. Hvad der iøvrigt måtte være af oplysninger om herremænd, vil blive inddraget $\mathrm{i}$ det forsøg på et perspektiv, som gennemgangen af materialet fra første halvdel af 1400-tallet giver anledning til.

\section{Slagten Røver (Henneskar?)}

I Hejsager var slægten Røver bosiddende. Kun to generationer af slægten kendes, nemlig Niels Røver, der levede ca. 1400 og havde fået en gård i Halk og en gård i $\mathrm{Nr}$. Vilstrup i pant af Jeppe Iversen (1423 22/7), samt hans to sønner Peter og Hans Røver, der 1421 2/2 kaldes brødre og til kapitlet i Haderslev solgte Gammelbykær og Smedegård samt endnu en gård i Hejsager. Dette brev er endvidere medbeseglet af en Tyge Røver (farbror?). 1420 2/96 havde Hans Røver pantsat de samme tre gårde til Tord Iversen, borger $\mathrm{i}$ 
Haderslev, og at en Peter Tordsen i 1453 kunne sælge en halvgård i Hejsager til ejerne af Bejerholm (se nedenfor) kunne tyde på, at ikke alle tre gårde er kommet $\mathrm{i}$ kapitlets varige besiddelse. Hermed stemmer også, at kapitlet ved reformationen ikke sad inde med så mange gårde $\mathrm{i}$ Hejsager, som det gennem tiden havde fået skøde på. 1443 4/8 skænkede Peter Røver endvidere til kapitlet to gårde i Hejsager, kaldet Pugholt, samt al rettighed i landsbyen Hjerndrup med samt hans brors rettigheder $\mathrm{i}$ hans faders gård, »da han er død og ingen ægte, levende børn efterlader sig «.

Dette brev fra 1443 skal formodentlig knyttes sammen med et ca. 100 år xldre brev, nemlig fra 1334 24/6, da Iver Nielsen af Hjerndrup havde ridder Jens Bondesens gods i Hejsager i pant. Iver Nielsen er formodentlig forfader til Peter og Hans Røver. Disse havde jo nemlig rettigheder i gods i Hjerndrup, og skønt brevet 1334 24/6 ikke på nogen måde angår Haderslev kapitel, findes det alligevel $i$ kapitlets arkiv. Det pantegods, der omtales her, er derfor formodentlig aldrig blevet indløst af Jens Bondesen, men nedarvet til Peder og Hans Røver. Da Peder Røvers gods kom til kapitlet, er brevet fra 1334 fulgt med. Som følge heraf må vi formodentlig opfatte $i$ hvert fald en del af Røver-slægtens gods i Hejsager som oprindeligt tilhørende ridder Jens Bondesen.

Slægten Røver har altså ca. 1400 ejet i hvert fald 7 gårde, nemlig 5 gårde i Hejsager (Gammelbykær, Smedegård + en tredje gård (1420 2/9, $14217 / 2$ ) samt de to gårde kaldet Pugholt (1443 4/8)), en gård i Halk og en gård i Nr. Vilstrup, erhvervet fra Jeppe Iversen (1423 22/7). Endvidere havde de gods eller rettigheder i gods i Hjerndrup (1443 4/8), formodentlig arvet fra deres forfædre. Måske er voldstedet $\mathrm{i}$ Henneskær deres hovedgård, beliggende som det er i engene øst for Hejsager (se nærmere herom side 36).

\section{Slagten Staverskov (Medstedgård)}

Den Jeppe Iversen, der nævnes 1423 22/7, er formodentlig identisk med Jeppe Iversen Staverskov, der 1422 29/10 solgte kapitlet i Haderslev sin gård Medstedgård i Halk, dog med genkøbsret inden 10 år. Han er formodentlig søn af den Iver Fallesen, der 1417 11/9 fik fribrev for Medstedgård af Erik af Pommern. ${ }^{7}$ Slægten er dog sikkert betydeligt $æ$ ldre, idet en Jeppe Staverskov nævnes som vidne $i$ et tingsvidne af Haderslev herredsting 1339 25/10. ${ }^{8} 14316 / 5$ 
medbeseglede en "Stuerskow « sammen med Niels Jensen af Lindet (Øster Lindet) for Lasse Clausen i Rejsby og 1438 28/7 medbesegler Jeppe Stagherskov for Niels Jensen. ${ }^{9}$ Af brevet 1431 kunne man formode, at Jeppe Staverskov var bosiddende i Lindet, idet medbeseglernes række slutter således: "Nicholaus Jenssen de Linwyt et Stuerskow ibidem“, dvs. sammesteds.

Erik Staverskov nævnes tre gange, 1457 1/2 og 25/2 samt 1462 20/12, alle tre gange medbeseglende for bisp Henrik Stangberg af Ribe, der også stammede fra Halk sogn (se nedenfor). ${ }^{10} 1457$ 1/2 medbeseglede han brev angående Henrik og Niels Stangbergs salg af Bejerholm til Iver Matzen. Om forklaringen herpå er, at Erik Staverskov selv var bosiddende i Halk sogn, og at slægten altså havde benyttet sig af sin genkøbsret, eller at han blot stod i et nært forhold til bispen af Ribe, således som de tre breve lader formode, er vanskeligt at afgøre. Den omstændighed, at Erik Staverskovs søn Oluf i 1490'erne var Ribe-bispens lensmand på bispeborgen Brink i Ballum sogn, ${ }^{11}$ samt at Jeppe Iversen Staverskov, der nok må opfattes som Eriks fader, synes at have tilknytning til $\varnothing$. Lindet, taler for den sidste formodning. Man må dog bemærke, at en Gregers Olufsen i 1543 sad på Medstedgård; han var måske en søn af Oluf Staverskov. ${ }^{12}$ Hertil kommer, at Medstedgård ikke var $\mathrm{i}$ kapitlets besiddelse ved reformationen.

Jeppe Iversen Staverskov har altså formodentlig ca. 1420 siddet på Medstedgård og hertil haft en gård i Halk og en gård i Nr. Vilstrup (måske dog allerede pantsat til Niels Røver). Hvor længe han eller hans slægt har siddet på Medstedgård, er dog som anført næppe til at afgøre helt sikkert.

\section{Slagterne Stangberg og Vognsen (Bejerbolm)}

Slægten Stangberg ejede ca. 1400 gården Bejerholm i Halk sogn, som den 1457 25/2 skødede til Iver Matzen. Dens hovedsæde var dog nok gården Keldet $\mathrm{i}$ Fjelstrup sogn med dens tilliggende $\mathrm{i}$ sognene nord for fjorden. ${ }^{13}$ Til Bejerholm synes ikke at have hørt andet gods på Haderslev Næs på dette tidspunkt, men en nøjere undersøgelse af et par andre herremænd og deres tilknytning til Næsset kan dog fremdrage et par gårde.

Peder Vognsen medbeseglede 1422 13/5 i Haderslev et vidne om gods på Haderslev Næs, men hører ellers hjemme på Sundeved, 
hvor han nævnes med gods i kong Eriks klageskrift okt. 1413.14 Hans svigerinde Ingerd Hermensdatter Pennow, gift med Nis eller Niels Vognsen og hjemmehørende mellem Vejle og Fredericia, skødede 1434 28/6 gods i Hejsager til Haderslev kapitel, dvs. disse to mænds tilknytning til Haderslev Næs er ret klart bevidnet. Men hvordan er forbindelsen, og hvorfra stammede dette gods?

Forbindelsen skal sikkert søges via Elsif Pedersdatter, der førte samme våben som Peter Vognsen. ${ }^{15}$ I et brev udstedt $\mathrm{i}$ Haderslev (NB) 1416 26/11 nævnes hun som enke efter Hartvig Bryske, en sjællandsk herremand. ${ }^{16} 1408$ 16/9 havde Hartvig Bryske udstedt et brev, der var medbeseglet af en række sjællandske riddere + de to sønderjyske væbnere Anders Stangberg og Nis Vognsen. ${ }^{17}$ Dette kan næppe forklares på anden måde, end at de har stået $\mathrm{i}$ slægtskabsforbindelse til Hartvig Bryske, nemlig via Elsif Pedersdatter: Nis Vognsen var hans kones farbror, det fremgår klart af kilderne, og Anders Stangberg må have været hans kones morbror, dvs. en søster til Anders Stangberg var gift med Peder Vognsen. Forbindelsen mellem slægten Stangberg og slægten Vognsen fremgår også af, at Anders Stangbergs søn Niels 1434 4/10 medbeseglede for Ingerd Hermensdatter, da hun solgte en gård i Gårslev mellem Vejle og Fredericia. ${ }^{18}$ Hendes gård i Hejsager går derfor utvivlsomt tilbage til slægten Stangberg. Peder Vognsen havde arvet den med sin hustru, og den er derefter arvet af deres datter Elsif, der er død uden arvinger, hvorefter den er gået tilbage til slægten, $i$ dette tilfælde repræsenteret ved Nis Vognsen (mærkeligt synes det, at den ikke er gået tilbage til Stangbergslægten). Slægtsforbindelsen fremgår af følgende oversigt:

\begin{tabular}{|c|c|c|c|c|}
\hline \multicolumn{2}{|c|}{$\begin{array}{c}\text { Jesse Stangberg } \\
\text { næunes } 1388 \text { og } 1389\end{array}$} & \multirow[b]{2}{*}{ g. m. } & \multicolumn{2}{|c|}{$\begin{array}{c}\text { Vogn Nielsen } \\
\text { nævnes } 1344-58\end{array}$} \\
\hline $\begin{array}{c}\text { Anders } \\
\text { Stangberg }\end{array}$ & datter & & Peder Vognsen & $\begin{array}{l}\text { Nis Vognsen } \\
\text { g. m. Ingerd }\end{array}$ \\
\hline & & & & $\begin{array}{c}\text { Hermensdatter } \\
\text { Pennow }\end{array}$ \\
\hline $\begin{array}{c}\text { Henrik Niels } \\
\text { Stangberg } \\
\text { solgte } 1457 \\
\text { Bejerholm }\end{array}$ & $\begin{array}{r}\text { Els } \\
\text { g.m }\end{array}$ & $\begin{array}{l}\text { Peders } \\
\text { Hartvig }\end{array}$ & $\begin{array}{l}\text { ter } \\
\text { yske }\end{array}$ & \\
\hline
\end{tabular}


Men Ingerd Hermensdatter Pennow synes at have haft andet gods $i$ Halk sogn. I en brevregistretur fra Maribo kloster siges det nemlig, at hun skænkede to (et andet sted siges tre) gårde i Halk sogn til klostret i Maribo. Det kendes ikke senere, men må i hvert fald antages at gå tilbage til slægten Stangberg på samme måde som gården, der skødes til kapitlet i Haderslev. ${ }^{19}$

Til Bejerholm har altså ca. 1400 hørt en gård i Hejsager + to, evt. tre gårde andetsteds i Halk sogn.

\section{En vabnerslagt $i \emptyset$ sby sogn}

Til Bejerholm hørte 15431 gård + 2 halvgårde i Hejsager samt 1/2 gård $\mathrm{i}$ Hajstrup og $1 / 2$ gård $\mathrm{i}$ Råde $\mathrm{i} \emptyset$ sby sogn. ${ }^{20}$ Dette gods har næppe oprindeligt hørt til Bejerholm, idet Henrik og Niels Stangbergs skøde 1457 25/2 kun omtaler Bejerholm, selvom skødet kun kendes i referat. I 1710 , da bl. a. alle frigårde og deres rettigheder på Haderslev Næs blev undersøgt, hedder det imidlertid, at der endnu på gården fandtes en række originaldokumenter vedrørende Bejerholm. Ifølge et brev udstedt $1392 \mathrm{købte}$ Jacob Matzen da af en "Edelmann Henneke Tiniatzen von Waapen $\ll$ (formodentlig = a wapn, dvs. væbner) »die kleinen Bauernhöfe« i $\varnothing$ sby sogn. Der er formodentlig tale om de to halvgårde $\mathrm{i}$ hhv. Hajstrup og Raade som nævnes 1543. Endvidere hedder det i 1710, at Matz Iversen 1453 købte en halv bondegård i Hejsager af en »Edelmann « Peter Tordsen. ${ }^{21}$ Denne Peter Tordsen er dog næppe adelig, men formodentlig søn af rådmand Tord Iversen i Haderslev, der nævnes 1439 1/9 og 1420 2/9 havde fået gods i Hejsager i pant af Hans Røver. ${ }^{22}$ Som nævnt ovenfor er det formodentlig en af disse gårde Peter Tordsen i 1453 sælger. Den omstændighed, at Bejerholm 1543 vitterlig har tilliggende i $\emptyset$ sby sogn og i Hejsager, og at Peter Tordsen kan knyttes til Tord Iversen, bevirker, at der næppe kan være grund til at tvivle på de sene oplysningers korrekthed, selv om navnet Henneke Tiniatzen synes forvansket, og væbnertitlen "a wapn“ er misforstået. Resultatet er altså, at vi kan formode, at en Jacob Matzen (bonde eller herremand?) 1392 erhvervede $1 / 2$ gård $\mathrm{i}$ Råde og 1/2 gård $\mathrm{i}$ Hajstrup fra en væbner Henneke Tiniatzen (eller hvad han nu har heddet), og at der altså ca. 1400 måske har siddet en lille herremand også helt imod øst på Næsset. Det er Jacob Matzens sønnesøn Iver 
Matzen, der 1457 erhvervede Bejerholm fra slægten Stangberg. Hans søn igen, Matthias Bejerholm, fik 1504 fribrev for Bejerholm af hertug Frederik. ${ }^{23}$

\section{Slagten Jytsen (Langmose)}

1530 28/6 stadfæstede hertug Christian frigårdsrettighederne for gården Langmose i Halk, der da tilhørte Hans Jytsen. ${ }^{24}$ Denne var formodentlig en efterkommer af den Henrik Jyde eller Jude, der 1430 27/3 fik adelsbrev af kong Erik af Pommern. ${ }^{25}$ Vi kan derfor nok regne med, at denne slægt har siddet på Langmose, i hvert fald fra ca. 1430, og Langmose er altså hermed at regne for en adelig sædegård, om end dens ejere kun har hørt hjemme på det laveste trin af den privilegerede klasses rangstige. Til Langmose har næppe hørt noget tilliggende gods, i hvert fald kendes noget sådant ikke før i 1500-tallet, hvor vi ved, at der er erhvervet gods til Langmose. ${ }^{26}$

\section{Slagten Lindenov (Hussted banke?)}

1584 9/1 skødede Hans Johansen Lindenov til kronen bl.a. tre gårde i Lønt, Starup sogn, og en gård i Stenderup, Grarup sogn. ${ }^{27}$ Hans Lindenovs farfars søster Anna Lindenov var gift med Otto Breide til Søbo på Als, der 1543 ejede bl.a. to gårde i Vandling, Starup sogn. ${ }^{28}$ Jeg har i en tidligere afhandling anfort, at disse seks gårde oprindelig må have tilhørt Diderik Thomesen og Lyder Dideriksen, der nævnes med tilknytning til Haderslev Næs i begyndelsen af 1400-tallet og tilhørte Lindenov-slægten. ${ }^{29}$

Diderik Thomesen medbeseglede for Hans og Peter Røver, da de 1421 2/2 skødede gods i Hejsager til kapitlet i Haderslev. Herudover nævnes han $\mathrm{i}$ forbindelse med sin broder Johannes Thomesen, en af dronning Margrethes mest betroede mænd (1386 $12 / 11,13923 / 3$ og 1407 23/11), samt 1421 4/8, da han medbeseglede vidnet om Sønderjyllands tilhørsforhold til Danmark. 1444 10/5 omtales han som død. ${ }^{30}$ Det eneste brev, der viser tilknytning til et bestemt område, er brevet $14212 / 2$, og at der er tale om tilknytning til Haderslev Næs, fremgår endvidere af, at en Lyder Dideriksen, hvis våben ganske vist ikke kendes, 1422 31/10 medbeseglede for Jep Iversen Staverskov, da denne udstedte brev angående Medstedgård. Der må uden tvivl være tale om en søn af Diderik Thomesen, 
og far og søns tilknytning til Haderslev Næs synes derfor klar nok. Jeg har endvidere i den ovenfor næunte afhandling fremsat den formodning, at deres hjemsted har været voldstedet Hussted banke ved Lønt. Denne formodning skyldes slægten Lindenovs besiddelse af de tre gårde i Lønt 1584. Udover disse tre gårde fandtes der kun en gård i Lønt, ejet af Tørning ${ }^{31}$, og slægten Lindenov var altså største jordbesidder her. Dette berettiger efter min opfattelse den fremsatte formodning. Gårdene i Vandling og Stenderup er endvidere beliggende så tæt ved Lønt, at også disse gårde formodentlig har været tilliggende til denne sædegård i Lønt.

Vi kan altså formode, at Diderik Thomesen ca. 1420 har været bosiddende i Lønt og hertil har haft mindst seks tilliggende fæstegårde. Hvordan han er kommet i besiddelse af dette gods, vides ikke, men giftermål er vel den mest sandsynlige mulighed, da slægten Lindenovs hjemsted ikke er Haderslev Næs. Hans søn Lyder efterlod sig ingen børn, hvorfor dette gods blev arvet af Diderik Thomesens brors slægt, $\mathrm{i}$ hvis besiddelse det var endnu $\mathrm{i}$ 1500-tallet.

\section{Slogten Møed (Vandlinggård)}

I 1500-tallet ejedes Vandlinggård af slægten Møed, hvis oprindelse er uvis, men formodentlig er den indvandret sydfra. ${ }^{32} \mathrm{Gårdens} \mathrm{først}$ kendte ejer er Klaus Møed, der kendes fra begyndelsen af 1500 -tallet. ${ }^{33}$ Gården må imidlertid allerede ca. 1420 have været ejet af slægten, idet Otto Møed 1422 13/5 medbeseglede et vidne udstedt i Haderslev ${ }^{34}$ og 1422 31/10 medbeseglede for Jep Staverskov angående Medstedgård. Dette er utvivlsomt tilstrækkeligt bevis for, at allerede han ejede Vandlinggård. Om gården har haft noget tilliggende fæstegods på dette tidspunkt er uvist, men det tilliggende, der nævnes 1543, i alt 13 hel- +2 halvgårde, er dels erhvervet i slutningen af 1400-tallet (i Slogs herred, ved giftermål fra slægten Emmiksen), dels tidligere kapitelsgods. ${ }^{35}$ Kun en gård i Halk kan have været oprindeligt tilliggende. De rester, vi har af selve hovedgården, viser som næunt et firesidet voldsted af herregårdsplads-typen. $\mathrm{Da}$ vi ved, at gården var genstand for store ombygninger i 1500-tallet, er det imidlertid muligt, at det først er resterne af denne 1500-tals hovedgård, vi har med at gøre, og at denne har afløst et ældre befæstet anlæg. ${ }^{36}$ 


\section{Slagten Tedinghusen (Vonsmose?)}

1389 25/7 medbeseglede Gotzick Tedinghusen for Esbern Tagesen (Emmiksen), da denne skødede en gård i Nr. Vilstrup til kapitlet i Haderslev. ${ }^{37} 1414$ 20/12 skænkede Gotzick Tedinghusens enke Eline Jensdatter en gård "Helved «, også i Nr. Vilstrup til kapitlet i Haderslev. Deres søn Henrik medbeseglede Hans og Peter Røvers flere gange næunte breve 1421 2/2, $142213 / 5$ og 31/10, og 1428 28/6 vidnede han angående Jens Skrams enke Elsabes skødning af gods i Simmersted til kapitlet i Haderslev. Der synes altså at være tale om en klar tilknytning til Haderslev-egnen, men hvad far og søn har ejet på Næsset, er vanskeligt at sige umiddelbart. Som fast holdepunkt haves kun gården i Nr. Vilstrup. Gotzick Tedinghusen har imidlertid også ejet jord i eller lige uden for Haderslev, idet en tilføjelse i Haderslev byret siger: „østen gamell kierke och szaa til then gamel vegh, det hauer Gosche Tedinghusze ... «. ${ }^{38}$ Hvor denne lokalitet skal søges, er dog ikke umiddelbart gennemskueligt.

Gotzick og hans broder Marquard Tedinghusen synes imidlertid at have haft en vis tilknytning til den mægtige Limbek-slægt på Tørning. Marquard Tedinghusen var 1385 10/10 Henneke Limbeks foged på Riberhus, som Henneke da sad inde med. 1397 18/3 medbeseglede han endvidere et skøde til Henneke Limbek. Gotzicks søn Henrik erhvervede 1437 23/10 halvdelen af Brændkjær mark ved Kolding, som havde tilhørt Henneke Limbeks hustru fru Jutta. ${ }^{39}$ Det er sikkert derfor via slægten Limbek, at vi skal lokalisere Gotzick Tedinghusen. 1417 4/10 skødede Claus Limbek nemlig til kapitlet gården Vonsmose i Vilstrup sogn. Det er her, der er spor af grave, og da Vonsmose endvidere ligger i umiddelbar nærhed af de lokaliteter, i tilknytning til hvilke Gotzick Tedinghusen nævnes, er det nærliggende at antage, at Gotzick har siddet på Vonsmose, ikke som ejer, men som foged for Claus Limbek for dennes omfattende gods på næesset. At han ved siden heraf selv har ejet gods, er der intet $\mathrm{i}$ vejen for. 1417 var han imidlertid forlængst død, således som det allerede fremgår af brevet 1414. Fogedembedet var vel derfor ledigt, men der var vel ikke længere brug for en foged her, især ikke da Claus Limbek 1417 skødede en lang række gårde på Næsset til kapitlet, heriblandt altså Vonsmose. 
Slagten Emmiksen (Bolet)

Også slægten Emmiksens besiddelse af et omfattende gods på Haderslev Næs skal nok, som anført af mig i Sønderjyske Årbøger 1972, forklares med en - formodentlig endda xgteskabelig forbindelse med Limbek'erne på Tørning. Ikke mindre end 29 gårde, først og fremmest i Vilstrup, Halk og $\varnothing$ sby sogne, kan formodentlig føres helt tilbage til Esbern Tagesen ca. 1400 og $\mathrm{i}$ hvert fald til hans sønner Emmike og Lyder. 1389 25/7 skødede Esbern nemlig en gård i Nr. Vilstrup til kapitlet $\mathrm{i}$ Haderslev, ${ }^{40} \mathrm{og}$ hans søn Lyder medbeseglede 1422 31/10 Jep Staverskovs brev angående Medstedgård. 1436 2/7 og 1451 28/4 medbeseglede broderen Emmike breve angående gods på Næsset. Disse personer har formodentlig haft deres hjemsted i Slogsherred, og den hovedgård, der nævnes som tilhørende efterkommere af dem, er næppe ældre som hovedgård end 1500 -tallet. Skal vi knytte slægten sammen med en befæstet gård på Næsset, må det formodentlig være Bolet, der tilhørte slægten i første halvdel af 1500-tallet. 1550 solgte nemlig Emmike Ottesens datter Anna, Bolet som et frit enemærke »wie es begraben und umdeichet ist « til en række af de større gårdbesiddere i Halk, bl.a. slægten Jytsen. ${ }^{41} \mathrm{Om}$ Bolet, dvs. det voldsted som endnu findes med sin mølledam, og som der uden

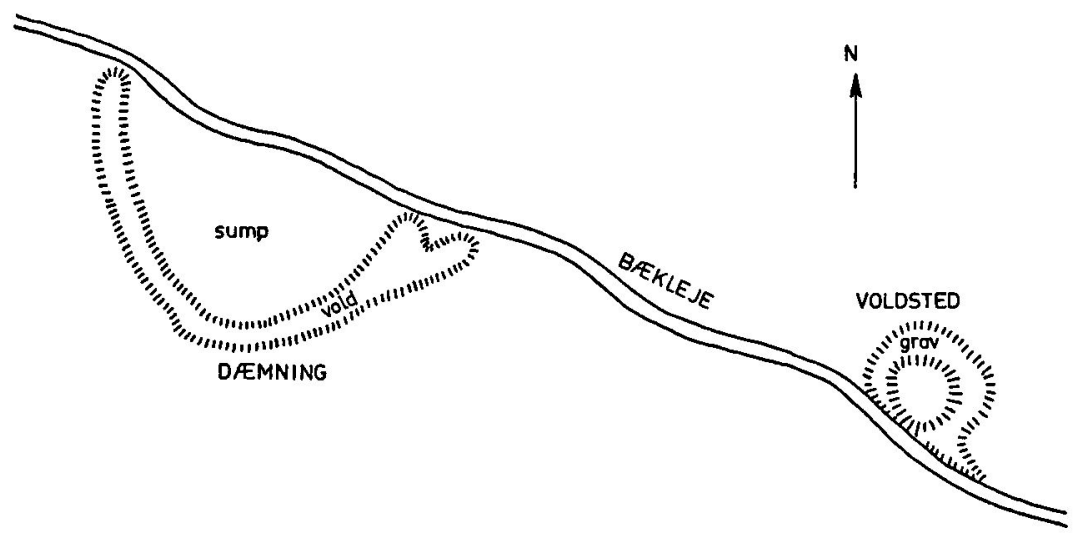

ANLEG I BOLET SKOV, HALK SOGN.

co. $1: 1000$

Skitse af voldstedet $i$ Bolet skov med selve borgbanken til bojre og damningen omkring den formodede mølledam til venstre. (Haderslev Museum) 
tvivl er tale om her, har været i Emmiksen-slægtens besiddelse helt tilbage omkring år 1400, vides ikke, men er vel sandsynligt i betragtning af det omfattende gods, slægten ejede på Næsset. Voldstedet er imidlertid meget lille, kun en banke på ca. $8 \times 8 \mathrm{~m}$ omsluttet af en grav, og står altså størrelsesmæssigt ikke i noget rimeligt forhold til slægtens godsmæssige position på Næsset. Men da slægten som nævnt formodentlig stammede fra Slogs herred og i løbet af første halvdel af 1400-tallet erhvervede sig Refsø ved Sommersted, skal vi måske blot opfatte dette voldsted som hjemsted for en lille herremand, hvis gods på en eller anden måde måske via Limbek'erne - er kommet i slægten Emmiksens besiddelse.

På et senere tidspunkt fik Emmiksen-slægten - eller rettere den del af den, som vi kan kalde Hejsagergårdlinjen - bopæl i selve Hejsager. 1587 30/5 skødede Magdalene og Margrethe Emmiksen til kronen bl.a. deres hovedgård Hejsager (gård nr. XII på kortet s. 34), der er beliggende lidt nordvest for selve landsbyen. Da Johan Norby $15877 / 7$ skødede sit gods i Hejsager, som også stammede fra slægten Emmiksen, omfattede skødet også den gård, Hejsager, hvorpå han selv boede (gård nr. II på kortet s. 34). ${ }^{42}$ Begge de to her nævnte gårde ligger ret højt på en skråning ned til møllebækken, og der kan måske have været grave rundt om.

\section{Otto Limbek (Kingsgård?)}

1451 12/11 nævnes Otto Limbek med gods i Kelstrup, da biskop Claus Wulf af Slesvig grundlagde en præbende i Vor Frue kirke i Haderslev. Hertil skænkede han bl.a. 8 marks indtægt, der var købt for 100 mark, »i væbneren Otto Limbeks gods i Vilstrup sogn i landsbyen Kelstrup«. 1434 28/6 havde Otto Limbek endvidere medbeseglet et vidne af Haderslev herredsting. Som navnet viser, tilhørte Otto Limbek den fremtrædende holstenske slægt Limbek, men hvordan slægtsforbindelsen er til de mægtige Limbek'ere på Tørning, vides ikke. Han har dog tilhørt en betydeligt mindre fremtrædende gren af slægten, og hans besiddelse af gods i Kelstrup skal sikkert ses i sammenhæng med Tørnings tilliggende gods på Haderslev Næs. Netop i Kelstrup havde Tørning et stort samlet antal gårde, 8 ialt, det største samlede antal i en enkelt landsby på Næsset. ${ }^{43}$ Dette er næppe nogen tilfældighed, idet der uden tvivl er 
tale om det gods, som Otto Limbek nævnes med i 1451, dvs. det har måske ikke været hans eget. Han kan blot have været foged for dette og andet af Tørnings gods på Næsset. Denne formodning bestyrkes af, at hverken hans datter, der var gift med Jon Bille, eller dennes evt. efterkommere ejede gods her. ${ }^{44}$ Ingen af de personer, vi træffer med gods på Næsset i 1500-tallet, kan i hvert fald føres tilbage til Otto Limbek. Vi kan derfor formode, at godset, da denne er død, er blevet inddraget under Tørning, der ikke længere har haft behov for en foged her, således som det formodentlig var tilfældet med Vonsmose tidligere i 1400-tallet.

Hvis Otto Limbek virkelig har haft de otte gårde i Kelstrup og måske andet gods på Næsset som foged under Tørning, kan man have en begrundet formodning om, at hans bopæl har været det voldsted, der findes ved Kingsgård i Kelstrup, netop dér, hvor det største antal samlede gårde var beliggende.

\section{Senere opståede bovedgårde}

Af de indledningsvis omtalte voldsteder er det kun Holmhøje, Ultanggård, Bodskov og voldstedet $\mathrm{i}$ Over Kestrup, som endnu ikke på en eller anden måde er blevet knyttet til en slægt eller person.

Hvad angår de to sidstnæunte skal de nok begge henføres til 1500-tallet. Bodskov viser rester af et firesidet voldsted af den såkaldte herregårdspladstype, der hører hjemme i hvert fald i denne periode, mens voldstedet $\mathrm{i}$ Kestrup er beliggende på en naturlig banke, ca. 25-30 m stor. De er formodentlig sammen med hovedgårdene Vilstrupgård (Vilstrup sogn) og Bjerningrød i Moltrup sogn nord for Haderslev opstået, samtidig med at Haderslev blev residensby, dels for hertug Christian 1523-33, og dels for hertug Hans den ældre 1544-80. Dette bevirkede, at egnen blev tiltrækkende for adelen, først og fremmest den holstenske, der ønskede at opholde sig i nærheden af det hertugelige hof, som de ofte selv tilhørte. Godske Rantzau skabte på grundlag af bl.a. Slesvig-bispens gods på Haderslev Næs et godskompleks med Vilstrupgård som centrum. Han var 1534 og igen 1545-49 amtmand på Haderslevhus. Hans søn Antonius (eller Tønnes) Rantzau arvede Vilstrupgård og solgte den med tilliggende til kronen 1583 11/9. Bjerningrød ejedes af Moritz Ahlefeldt (død 


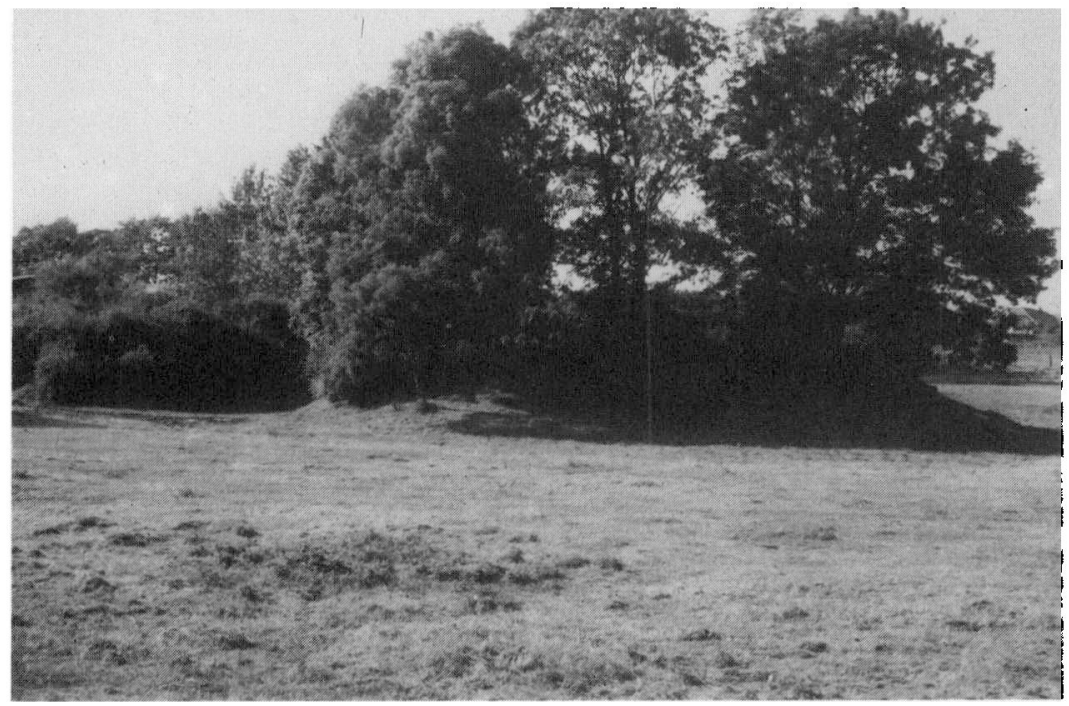

Voldstedet Kingsgård ved Kelstrup set fra sydøst. I forgrunden den trabevoksede hovedbanke, $i$ baggrunden til venstre den kratbevoksede forborg. Voldstedet borer til middelalderens tvedelte type. Fotografi 1976.

1588), der var hertug Hans den ældres befalingsmand på Mårkær (Mohrkirchen), et tidligere kloster i Angel, og desuden ejede et hus i Haderslev; 1588 12/1 skødede han Bjerningrød til kronen. Bodskov ejedes af Povl Breide og kom ca. 1550 ved giftermål til slægten Høk, der også ejede Kestrup. 1584 15/2 blev Kestrup og Bodskov med tilliggende solgt til kronen af Didrik Høk, hvis fader Moritz Høk som ejer af Kestrup havde været marskalk hos hertug Hans på Haderslevhus, mens Didrik Høk selv nævnes som hofsinde hos hertugen $1576 .{ }^{45}$

Det er bemærkelsesværdigt, at alt dette gods bliver solgt kort tid efter hertug Hans' død 1580, og at de fleste af de personer, der har ejet det, har haft en eller anden tilknytning til hertugen og hans hof. Disse to omstændigheder sammenholdt med, at ingen af disse lokaliteter nævnes som hovedgårde før i 1500-tallet, og med voldstedernes udseende, er et indicium for den fremførte formodning: disse voldsteder hører først hjemme i 1500-tallet.

I de tre hovedgårdes tilliggende indgår forskellige grupper af gods. Godske Rantzau, der ejede Vilstrupgård, havde således 


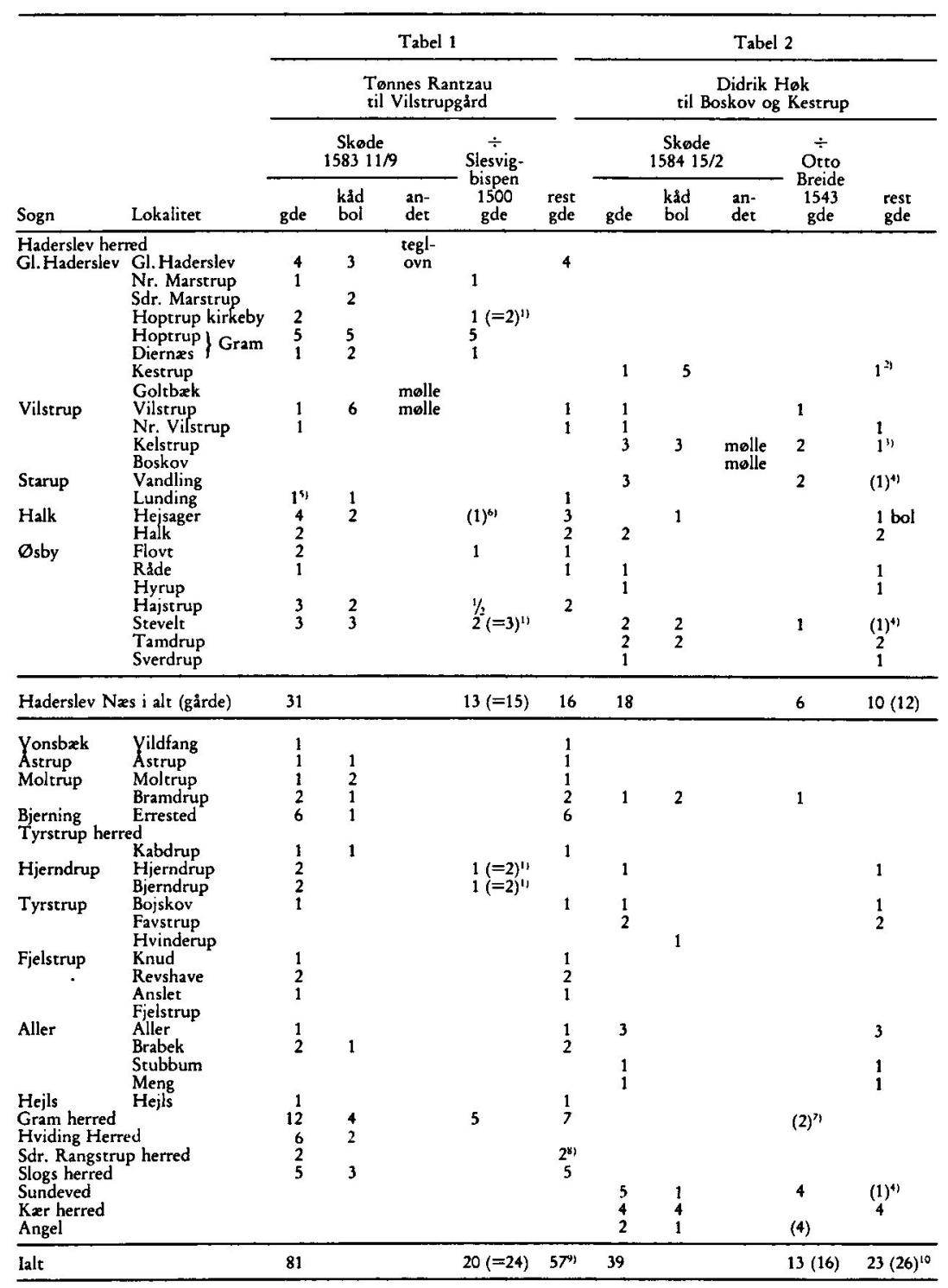

Kilder: Skøderne: Kr. Sk. I; Slesvig-bispen 1509: se note 46; Otto Breide 1543: Sk. og Jb. s. 432.

\section{Noter}

1) Alle gårde 1583 betaler gæsteri. Der er altsá tale om gårddelinger mellem 1509 og 1583.

2) = hovedgården Kestrup.

3) = hovedgården Boskov, der formentlig går tilbage til slagten v.d.Wisch.

4) Der kan vxre tale om gårddelinger 1543-84, således at Orto Breides gárde 1543 omfatter alle gårdene 1584.

5) Kr. Sk. I siger 3 garde, Haderslevhus lens jordebog $1596-97$ siger 1 gấrd, der ma være det rigtige.

6) Gården stammer formodentlig fra Haderslev kapitel. Identifikation ved hjxlp af navn og afgifter. 
erhvervet det meste af Slesvig-bispens jordegods omkring Haderslev. Ved en sammenligning af afgifterne for bispens gods i $1509^{46}$ og de afgifter, der betales af Tønnes Rantzaus tidligere fæstere ifølge jordebogen 1596-9747, kan disse tidligere bispegårde klart udskilles. Der er tale om alle de gårde, der 1596-97 betaler gæsteri. Det drejer sig om 23 gårde (tallet er større end Slesvig-bispens 1509, men det skyldes gårddelinger i den mellemliggende tid), og hertil kommer 1 gård fra Haderslev kapitel, dvs. 24 af ialt 81 gårde, og af de resterende 57 er de 16 beliggende på Haderslev Næs, 11 i Haderslev herred nord for fjorden og $10 \mathrm{i}$ Tyrstrup herred (jvf. tabel 1). De var altså erhvervet på anden måde.

I Didrik Høks gods indgår tre grupper af forskellig oprindelse, dels (1) det gods han arvede fra sin fader Moritz Høk, der 1564 skrives til Kestrup med 14 plove (=14 gårde), dels det gods han arvede med sin hustru Mette Breide, hvis fader Povl Breide i 1564 anføres med 33 plove (= gårde) til Bodskov. ${ }^{48}$ Disse 33 gårde igen bestod af, (2) hvad Povl Breide havde arvet efter sin fader Otto Breide til Søbo, og (3) hvad han havde fået med sin hustru. Otto Breides gårde, der kendes $1543^{49}$, genfindes meget let blandt Didrik Høks gårde i 1584, da han skødede sit gods til kronen, og de udgjorde da 13, muligvis 16, af de 39 gårde. Hovedparten af disse 13 gårde stammede igen fra Otto Breides hustru Anna Lindenov og går tilbage til slægten Emmiksen. ${ }^{50}$ Af Didrik Høks 39 gårde bliver altså tilbage 26 (eventuelt 23) gårde, hvoraf de 10 (eventuelt kun 8) + Kestrup og Bodskov (ialt 12) er beliggende på Haderslev Næs og i Tyrstrup herred (jfr. tabel 2). Disse 26 (23) gårde omfatter dels Moritz Høks 14 gårde, der nævnes 1564, dels hvad Povl Breide havde arvet med sin hustru, som menes at være et medlem af slægten v.d. Wisch, formodentlig en datter af Henneke v.d. Wisch på Ejsbøl. ${ }^{51}$

Der er formodentlig en slægtsforbindelse mellem Rantzau'erne på Vilstrupgård og Høk'erne på Kestrup. Moritz Høks moder var ifølge Danmarks Adels Aarbog 1950 Anna Rantzau til Vamdrup. Hun genfindes ikke i Aarbogens stamtavle over slægten Rantzau

7) Ejes ikke af Didrik Hok 1584.

8) Mageskiftet fra Logumkloster $15397 / 8$, Scriptores Rerum Danicarum bd. 8 (Logumbogen) s. 50 .

9) 1583 ialt 81 gårde, heraf stammer de 20, der 1509-83 ved delinger er blever til 24 gårde fra Slesvig-bispen og Haderslev kapitel, rest 57 gårde.

10) 158439 gårde, hvoraf 13, muligvis 16 (jfr. note 4) går tilbage til Otto Breide, rest 23 eller 26 gårde. 
(1930), men der må uden tvivl være tale om en søster til Godske Rantzau til Vilstrupgård, som også ejede Vamdrupgård. Deres moder, Drude Rantzau, var datter af Peter Rantzau, amtmand i Haderslev 1483, og Margrethe v. Ahlefeldt, en datter af Benedict Ahlefeldt til Tørning. Slægtssammenhængen fremgår af oversigten s. 25.

Det fremgår altså af denne slægtssammenhæng, at disse personer, som i 1580'erne sælger gods til kronen, allesammen viser en forbindelse tilbage til Limbek'erne på Tørning, og der kan næppe være tvivl om, at deres gårde (bortset fra de gårde der stammede fra kirken) for hovedpartens vedkommende må gå tilbage til Limbek'erne. Enkelte gårde kan være købt til eller mageskiftet, mens de sad på deres hovedgårde, men grundstammen i deres gods må være Limbekgods.

Af Tønnes Rantzaus 81 gårde kan som nævnt 24 gårde udskilles som tidligere kirkegods. Til rest bliver 57. Dette overstiger formodentlig, hvad Peter Rantzau har arvet med sin hustru Margrethe Ahlefeldt til Tørning, idet hans svigersøn Tønnes Rantzau (den ældre) i et register 1507 nævnes med 231/2 plov. ${ }^{52}$ Af de 57 gårde var det imidlertid kun de 44, der var beliggende indenfor det område, hvor Limbek'ernes gods hovedsagelig var beliggende, nemlig Tyrstrup, Haderslev og Gram herreder, og vi kan altså sige, at disse 44 gårde indicerer, hvor også Peter Rantzaus gårde var beliggende.

Problemet bliver derefter af Didrik Høks gårde at udskille Moritz Høks 14 gårde eller sagt på en anden måde de gårde, som Povl Breide havde arvet med sin hustru NN v.d. Wisch (jvf. slægtsoversigten). Dette har vi imidlertid ingen mulighed for, da ingen kilder står til vores rådighed hertil. Af tabel 2 ses det imidlertid, at Povl Breide højst kan have fået ca. 20 gårde med sin hustru (han nævnes med 33 gårde 1564, hvoraf $\mathrm{i}$ hvert fald 13 var arv fra faderen Otto Breide (1543)). Når hertil kommer, at de 14 af Didrik Høks 21 gårde på Haderslev Næs og i Tyrstrup herred,som ikke går tilbage til Otto Breide (jfr. tabel 2), må stamme fra Morits Høk (1564), kan det næppe være mere end 7-8 gårde i disse to områder, som går tilbage til slægten v.d. Wisch.

Når vi derfor vil forsøge at afgøre, hvor mange af de gårde, som i 1580'erne er i Antonius Rantzaus og Didrik Høks besiddelse, der 
Oversigt over slagterne Rantzau, Høk og Breides forbindelse med Limbek'erne og Ablefeldt'erne til Torning

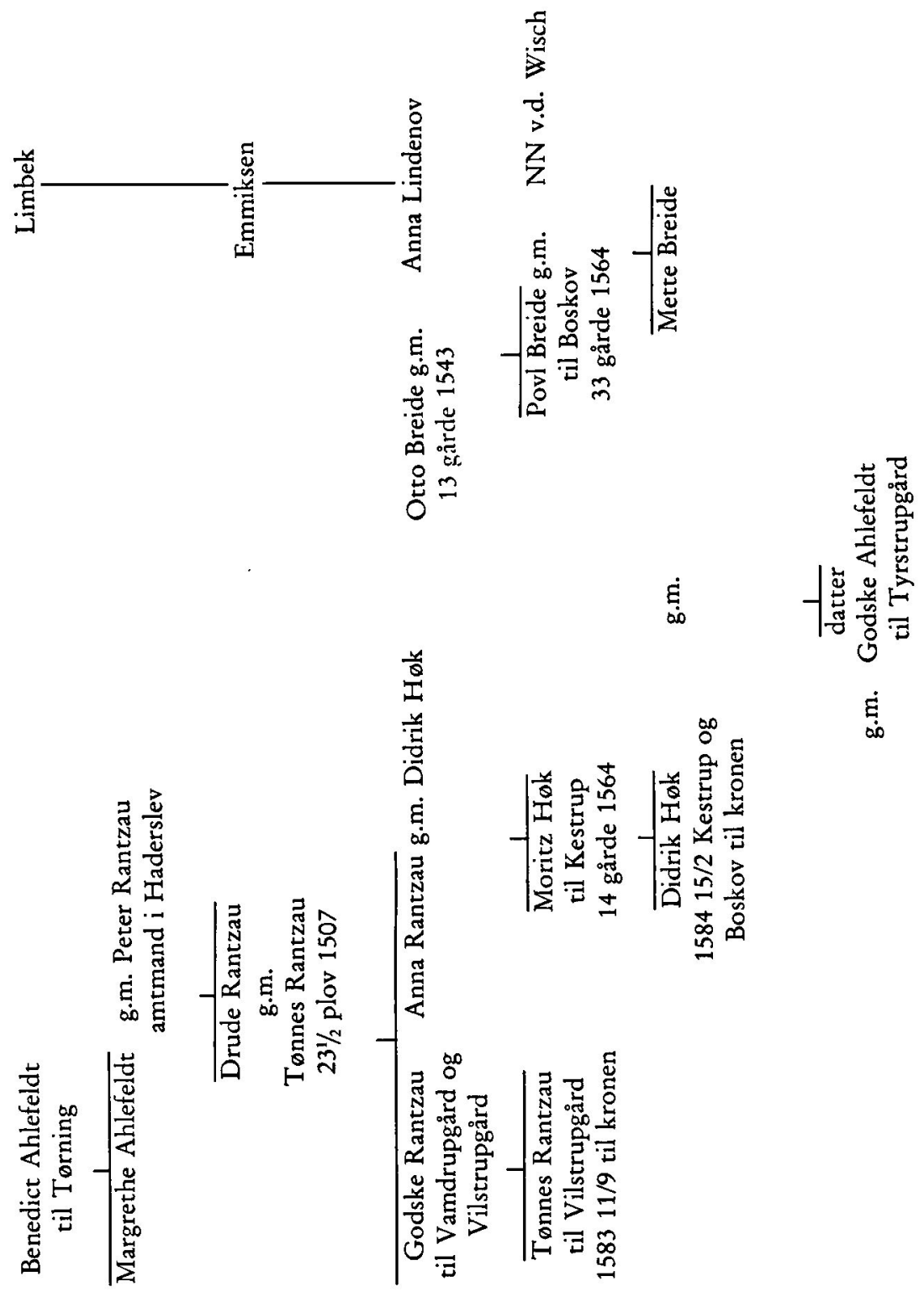


går tilbage til ejerne af Tørning, må vi altså tage disse usikkerhedsmomenter med: Tønnes Rantzau ejede i 1583 formodentlig flere gårde på Næsset end arven fra Limbek'erne omfattede, og en del men formodentlig kun en ringe del - af Didrik Høks gårde går tilbage til slægten v.d. Wisch på Ejsbøl. En sammenligning af beliggenheden af Didrik Høks 21 gårde og Antonius Rantzaus 37 gårde $\mathrm{i}$ Haderslev og Tyrstrup herreder med beliggenheden af de gårde inden for de samme områder, som vi med sikkérhed ved har hørt under Tørning, (se tabel 3, side 29), viser, at der i en lang række tilfælde er tale om gods i de samme landsbyer, og at de tre forskellige grupper af gods vi her opererer med (Didrik Høks, Antonius Rantzaus og Tornings) koncentrerer sig i de samme sogne. Dette ses måske tydeligst i Tyrstrup herred, hvor der hovedsagelig er tale om Fjelstrup, Aller, Tyrstrup og Hejls sogne. Tørning har ganske vist ikke meget gods i Fjelstrup sogn, men hvis vi medregner de gårde, som 1461 og 1446 kom fra Tørning til Haderslev kapitel ${ }^{53}$, bliver der tale om ret betydeligt Torninggods netop i de landsbyer, hvor Antonius Rantzau og Didrik Høk har gods; især bemærkes Stubbum og Brabek i Aller Sogn.

Vi må altså konkludere, at en væsentlig del af Antonius Rantzaus og Didrik Høks gårde på Haderslev Næs, ialt 20-25, går tilbage til slægten Limbek på Tørning. Sammenholder vi dette med slægten Emmiksens besiddelse af gods på Næsset, som formodentlig også stammede fra slægten Limbek, samt Otto Limbeks og Gotzick Tedinghusens tilsyneladende funktion som fogeder for Limbek'erne åbner der sig perspektiver bagud, som er særdeles interessante, og som skal omtales nedenfor.

\section{Forsøg på et perspektiv}

Med denne gennemgang af det skriftlige kildemateriale og de slægter, der nævnes i dette, er det lykkedes at knytte alle voldsteder med undtagelse af Holmhøje mere eller mindre sikkert sammen med personer og slægter nævnt i det skriftlige kildemateriale. Men denne sammenhæng synes samtidig at åbne et særdeles interessant perspektiv, som jeg her skal forsøge at skitsere. Det kan imidlertid kun blive en skitse, da kildematerialet trods alt må anses for ret spinkelt.

En række voldsteder af den såkaldte herregårdspladstype kan 
næppe føres særligt langt tilbage i tiden. Det gælder Langmose og Vandlinggård (hhv. slægterne Jytsen og Møed), der sikkert ikke kan være ældre end begyndelsen af 1400-tallet, samt Bodskov og Kestrup, der formodentlig sammen med Vilstrupgård først er opstået i 1500-tallet.

En række voldsteder peger både på grundlag af de skriftlige og arkæologiske vidnesbyrd bagud. Det gælder Henneskær, hvor der er en forbindelse mellem slægten Røver og personer, der nævnes $i$ 1330 'erne, og Hussted banke, der som næunt næppe kan være „fødested « for de to mænd af slægten Lindenov, der synes at kunne knyttes hertil. Bolet, Kingsgård og Vonsmose er på samme måde små voldsteder af den tvedelte type med borgbanke og forborg. De viser forbindelse tilbage til slægten Limbek og formodentlig derfor endnu længere tilbage (jfr. nedenfor). Holmhøje er det eneste voldsted, hvorover det skriftlige kildemateriale ikke kaster lys, men også dets form viser tilbage i tiden og ikke frem. Hertil kommer så de to gårde Medstedgård og Bejerholm, der ikke afgiver noget arkæologisk vidnesbyrd, men hvor det skriftlige kildemateriale viser, at de må have eksisteret som herremandsbesiddelser allerede før år $1400 . .^{54}$

Vi har altså at gøre med seks ret små voldsteder + to andre gårde, der alle peger tilbage til tiden før 1400. Kun på tre af disse (Henneskær, Medstedgård og Bejerholm) sidder der imidlertid $\mathrm{i}$ 1400-tallet slægter, der må antages at være gamle på egnen. De øvrige, bortset fra Holmhøje, synes enten overtaget af udefrakommende små-slægter (Hussted banke og Vandlinggård) eller af egnens mægtigste slægt, Limbek'erne og deres arvtagere eller vasaller og fogeder (Bolet, Kingsgård og Vonsmose).

Disse besiddelsesforhold lader ane store strukturelle ændringer i tiden omkring 1400, og det er sikkert derfor, at det er så godt som umuligt at knytte forbindelsen mellem personerne og slægterne her og så den række herremænd, formodentlig alle bosiddende i Haderslev herred, der nævnes i et tingsvidne $1339 .{ }^{55}$ De personer der nævnes som vidner her, er Jacob Grubbe, Jacob Nielsen, Christian Knudsen, Niels Myndelin, Niels Hjort, Iver Grubbe, Jens Staverskov, Lars Iversen, Jon Iversen og Bennike og Ebbe Jensen. Brevudsteder er fru Gertrud, Jens Bondesens enke, og hendes søn Ove. Som det ses er det kun én person, Jens Staverskov, 
som det er muligt at knytte sammen med en person i 1400-tallet, nemlig Jeppe Staverskov på Medstedgård, medens Jens Bondesen som tidligere nævnt kan knyttes til slægten Røvers gods i Hejsager.

Dette brev er det ældste vidnesbyrd om herremænd på Næsset, og selvom det er en enkeltstående kilde, og personerne ikke kan stedfæstes, bekræfter det dog den formodning om en talrig herremandsstand på Næsset, som voldstederne giver anledning til. $\mathrm{Da}$ brevet kun findes i afskrift, og vi derfor ikke har den hjælp til en evt. identifikation, som seglene giver, kan dette naturligvis være medvirkende til, at vi ikke kan knytte forbindelsen frem til begyndelsen af 1400-tallet. Men som næunt sidder der kun på tre af de hovedgårde, vi har med at gøre i begyndelsen af 1400-tallet, slægter, der må antages at være gamle på egnen.

\section{Godssamling hos Limbek'erne}

Hvor er disse personer, der nævnes 1339, eller rettere, hvor er deres efterkommere da blevet af, og - hvad der er mere interessant - hvor er det gods, de har ejet, blevet af? Spørgsmålet er, om løsningen på dette problem ikke skal søges $\mathrm{i}$ den omstændighed, at vi tilsyneladende finder Limbek'erne stærkt repræsenteret på Næsset $i$ begyndelsen af 1400-tallet. Vi ser $i$ hvert fald, at slægten tilsyneladende kan knyttes til tre voldsteder, Bolet (gennem slægten Emmiksen), Vonsmose (gennem slægten Tedinghusen og solgt af Claus Limbek 1417) og formodentlig også Kingsgård (gennem Otto Limbek). Hertil kommer så et særdeles omfattende antal fæstegårde. 1543 nævnes 30 fæstegårde på Næsset som tidligere Tørning-tjenere ${ }^{56}, 14174 / 10$ havde Claus Limbek skødet 12 gårde på Næsset til kapitlet i Haderslev, heriblandt også Vonsmose, og hertil kommer slægten Emmiksens gods, ialt 30 gårde, der som nævnt må antages at stamme fra Limbek'erne. Også en række fæstegårde under de tre hovedgårde fra 1500-tallet, Bodskov, Kestrup og Vilstrupgård synes imidlertid som nævnt at gå tilbage til slægten Limbek. Lægges disse ca. 25 fæstegårde til de ovenfor næunte ca. 70 gårde, fås henved 100 fæstegårde, der i 1400-tallet synes at have hørt under Tørning. De var beliggende, således som det fremgår af tabel 3.57

Tænker vi os, at disse 70-100 gårde så nogenlunde er udtryk for, hvad denne mægtige slægt har haft af gods på Næsset - tallet er ikke 
Tabel 3. Formodet Tørning-gods på Haderslev Næs ca. 1400

\begin{tabular}{|c|c|c|c|c|c|c|c|}
\hline \multirow[b]{2}{*}{ Sogn } & \multirow[b]{2}{*}{ Lokalitet } & \multicolumn{2}{|c|}{ Torning } & \multirow[b]{2}{*}{$\begin{array}{c}\text { Slægren } \\
\text { Emmiksen }\end{array}$} & \multirow[b]{2}{*}{$\begin{array}{l}\text { Slxgten } \\
\text { Høk }\end{array}$} & \multirow[b]{2}{*}{$\begin{array}{l}\text { Slzgten } \\
\text { Rantzau }\end{array}$} & \multirow[b]{2}{*}{ Ialt } \\
\hline & & 1543 & $\begin{array}{c}\text { til Had. } \\
\text { kapitel } \\
1417\end{array}$ & & & & \\
\hline \multirow{4}{*}{$\begin{array}{l}\text { Gl. Haderslev } \\
\text { Hoptrup }\end{array}$} & Gl. Haderslev & & & & & 4 & $4 ?$ \\
\hline & Nr. Marstrup & 2 & \}$_{1}$ & & & & \}$_{10}$ \\
\hline & $\begin{array}{l}\text { Sdr. Marstrup } \\
\text { Hoptrup kirkeby }\end{array}$ & $\begin{array}{l}7 \\
5\end{array}$ & $3^{1}$ & & & & \}$_{5}^{10}$ \\
\hline & Kestrup & & 1 (ade) & & 1 & & 2 \\
\hline \multirow[t]{3}{*}{ Vilstrup } & Sdr. Vilstrup & & & 4 & & 1 & 5 \\
\hline & Nr. Vilstrup & & & & 1 & $i$ & 2 \\
\hline & $\begin{array}{l}\text { Vonsmose } \\
\text { Kelstrup }\end{array}$ & 7 & 1 & 3 & & & 1 \\
\hline \multirow[t]{3}{*}{ Starup } & Vandling & 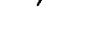 & & 3 & (1) & & (1) \\
\hline & Lunding & & & 1 & & 1 & 2 \\
\hline & Lont & 1 & & & & & 1 \\
\hline \multirow[t]{5}{*}{ Halk } & Halk & i & & 6 & 2 & 2 & 11 \\
\hline & Hejsager & 1 (bol?) & 1 & hdg $+32 / 2^{\prime \prime}$ & 1 bol & 3 & 9 \\
\hline & $\begin{array}{l}\text { 1 ange } \\
\text { Ultang }\end{array}$ & 1 & & & & & $\begin{array}{l}1 \\
1\end{array}$ \\
\hline & Lilholt & 2 & & & & & 2 \\
\hline & $\begin{array}{l}\text { Medsted } \\
\text { Sode }\end{array}$ & & & $\begin{array}{l}1 \text { bol } \\
1\end{array}$ & & & 1 \\
\hline \multirow{8}{*}{ Osby } & Flovt & $1^{2 \prime}$ & & & & 1 & 2 \\
\hline & Rade & & 1 & 4 & 1 & 1 & 7 \\
\hline & Hyrup & $2+1$ bol & 1 & & 1 & & 4 \\
\hline & Hajstrup & 1 & 3 & 1 & & 2 & 7 \\
\hline & $\begin{array}{l}\text { Nordgard } \\
\text { Osby }\end{array}$ & 1 & 2 & & & & 3 \\
\hline & Stevelt & 1 & & $3+1 \mathrm{kåd}$ & (1) & & $4(5)$ \\
\hline & Tamdrup & & & & 2 & & 2 \\
\hline & Børløsgard & & 1 & & & & $\begin{array}{l}1 \\
1\end{array}$ \\
\hline I alt & & 32 & 12 & 29 & $9(11)^{31}$ & 16 & $\begin{array}{c}98 \\
(100)\end{array}$ \\
\hline
\end{tabular}

Kilder: Torning 1543: Sk. og Jb. s. 75-77, 1417: Arsberetninger fra det kongelige Geheime-Archiv bd. 2 1856, tillæg s. 12. Slxgten Emmiksen: Sonderiyske årboger 1973 s. 41.

Slxgten Hok: Tabel 2, spalten *rest*.
Slagten Rantzau: Tabel 1, spalten *rest*.

Parantes om gárdtal angiver at tilhørsforholdet er usikkert, jfr. note 4 til tabel 1. I sammentællingerne, badde lodret og vandret, er kád og bol ikke medtaget.

1) Johan Norby har $15877 / 72$ fxstere på én gärd, Kr. Sk. I.

2) Iflg. register 1580 . lavere end $i$ tabel 2.

overraskende stort i sammenligning med, hvad slægten ejede andetsteds i Nordslesvig - synes det vitterligt, som om vi her er ved at nå frem til forklaringen på, at vi ikke kender ret mange efterkommere af de 12 herremænd 1339. Det må være Limbek'erne, der på en eller anden måde har overtaget deres hovedgårde og øvrige gods, $\mathrm{i}$ hvert fald kan tre voldsteder knyttes til denne slægt, og de er næppe opført af den.

Det er naturligt at spørge om, hvordan og især hvorfor en sådan overtagelse af gods har fundet sted. Spørgsmålet om hvordan kan ikke besvares fyldestgørende, da vi intet materiale har, der fortæller om en sådan overgang af herremandsgods til de store jorddrotter på Tørning. Vi har imidlertid et enkelt brev fra Vestslesvig, der 
illustrerer, hvorledes Limbek'erne fra forskellig side havde erhvervet gods i en enkelt landsby, således at slægten kom $i$ besiddelse af en stor del af landsbyen. 1355 22/2 skødede Catharina, enke efter Johan Limbek til Trøjborg, til klostret i Løgum et ret omfattende gods $\mathrm{i}$ landsbyen Borg i Brede sogn. ${ }^{58}$ Godset opregnes meget detaljeret i skødet og omfattede " 2 huse, som hun havde fra Peter Kaas' arvinger, endvidere på Borg mark 14 øre jord, som hun havde fra Johannes Tygesen, 19 ørtug jord, som hun havde fra Ketil Marthensen, 4 ørtug jord, som hun havde fra Gase Sort, 16 ørtug jord, som hun havde fra Ingerd Timmes, 2 øre jord, som hun havde fra Andreas Kajsen, $7 \frac{1}{2}$ ørtug som hun havde fra Niels Kajsøn; endvidere i Borgholm $1 / 2$ øre jord $\ll$. Den årlige indtægt var 4 mark korn.

Af de i dette brev nævnte personer kan kun en, Johannes Tygesen med rimelighed opfattes som herremand ${ }^{59}$, men brevet illustrerer på udmærket vis, hvordan denne mægtige adelsslægt har opkøbt jord i denne landsby. Det var nok ikke det eneste sted, det skete, og Johannes Tygesen var ikke den eneste herremand, det gik ud over. Vi kan sikkert forestille os, at det samme er sket på Haderslev Næs, selvom ikke et eneste brev viser, at Limbek'erne har opkøbt eller erhvervet jord her.

\section{Endring i ejendomsstrukturen}

En enkelt lille brevregistratur, næsten det dårligst tænkelige vidnesbyrd, men dog bedre end ingenting, viser dog, at processen var igang på Næsset, selvom det her er kronen, der står som opkøber. I kronens $æ$ ldste arkivregistraturer er registreret et brev, ifølge hvilket Per Friis til kong Valdemar (Atterdag) i 1373 pantsatte sit gods i Haderslev herred "som ær then gard Hesagher met ij (2) landboo. Item iiij (4) landzgaardhæ som pleyæ at giffwe hwært aar i (1) halff læst korn. Item i Halkæ ij (2) gaardhæ som skylle j (1) læst korn. Item østen hooss Heesagher i (1) gaard som skyller ij (2) øræ korn oc alt annet godz som han hadhæ innen Hathersleffherit ${ }^{60}{ }^{60}$

En lille herremand pantsætter altså alt sit gods på Haderslev Næs. Hvorfor? Pengenød må vel have været den umiddelbare årsag, og denne pengenød kan næppe være forårsaget af andet end svigtende indtægter af det gods, han ejede, som følge af de 
krisetilstande, der i denne periode herskede inden for landbruget $\mathrm{i}$ hele Vesteuropa. Hvad enten årsagen hertil nu var en befolkningstilbagegang eller en afvandring fra landbruget på grund af »dårlige tider «, så betød dette, at det i stigende grad blev vanskeligt for jordejerne at få jorden dyrket. Det betød, at det måtte gøres tillokkende at indgå i et fæsteforhold, og det kunne gøres dels ved at sætte landgilden ned, dels ved at foretage en omfordeling af jorden, således at de små landbrugsenheder fik lagt jord til fra de større gårde, og der istedet opstod mere ensartede "familiebrug «.

Per Friis' pantebrev synes også at antyde denne proces. De afgifter, der betales af hans gårde, var meget høje i forhold til 1500 tallets afgifter. Ingen gård i Hejsager betalte i 1500-tallet mere end 3 øre korn og den almindeligste afgift var 1-2 øre, mens en halv læst korn svarer til 4 øre. Det antyder, at disse gårde har været større end 1500-tallets. Ligeledes bemærkes det, at der til »den gård Hejsager « hører to landboer. Det kunne tyde på, at denne gård har været drevet ved hjælp af datidens landarbejdere, som har haft ingen eller kun ringe jord, og istedet har måttet tjene deres usle løn ved at arbejde på hovedgården. Det er disse landbogårde, som det blev vanskeligere og vanskeligere at holde besat, og det er dette, der bl. a. betinger en omlægning af ejendomsstrukturen.

En tredje ting, der springer $\mathrm{i}$ øjnene, er, at det om de fire »landzgaardhæu siges, at de plejer at give $1 / 2$ læst korn om året. Dette skal måske forstås på den måde, at de ikke længere ydede så meget, og at Per Friis har haft svært ved at gennemtvinge betalingen af landgilden, at han altså er blevet ramt af svigtende indtægter.

Per Frïs' pantebrev synes således på udmærket vis at illustrere den omstruktureringsproces, der var igang, men det er naturligvis et enkeltstående vidnesbyrd, som ikke kan bevise, at ejendomsstrukturen overalt på Næsset var som på Per Friis’ gods, og at man der havde de samme problemer at slås med. At ejendomsstrukturen også i Nordslesvig ligesom i det øvrige land har været anderledes i 1300-tallet, end den var i 1500-tallet, er der dog adskillige vidnesbyrd om rundt omkring fra landsdelen. C. A. Christensen har for Løjtlands vedkommende vist, hvorledes der på Slesvigbispens gods her fandtes et par meget store fæstegårde, hvoraf en var en såkaldt brydegård, med tilhørende landboer, der havde 
arbejdspligt til brydegården. ${ }^{61}$ Løjtland ligger ligesom Næsset ved østkysten, og selvom det nok er mere kuperet, er jordbundsforholdene dog nogenlunde de samme, hvorfor man også kan formode, at landbrugsstrukturen er nogenlunde ens. Fra Vestslesvig, hvor kildematerialet er bedre, haves flere vidnesbyrd om en ældre ejendomsstruktur, end det er tilfældet for $\emptyset_{\text {stslesvig. I Ullerup i }}$ Skærbæk sogn havde Knud Degn af slægten Slet ca. 1300 en brydegård, der ydede 7 øre korn, og hertil fem landboer, der hver ydede $7 \frac{1}{2}$ ortug penge. I 1320 nævnes en »fundus coloniae«, dvs. toften til en landbogård i Løjtved ved Løgumkloster, i 1345 en gård i Vellerup i Agerskov sogn, der ydede 1 øre rug, med to landboer, og i 1349 gården Tornskov ved Løgumkloster, der ydede 6 øre korn og havde to tilliggende landboer. Fra egnen lige syd for Ribe (V. Vedsted sogn) haves adskillige vidnesbyrd om landboer fra 1300tallets første halvdel..$^{62}$ Det samlede antal kildeudsagn fra hele Danmark om landboer i 1300-tallet er iøvrigt ikke særligt stort ${ }^{63}$, og intet tyder på, at ejendomsstrukturen har været væsentlig anderledes i Nordslesvig end i det øvrige Danmark. De større gårde har dog næppe været helt så store som i kongeriget, og stordriften vel næppe heller så udbredt som den synes at have været i hvert fald på Sjælland, men at landboerne må have været en væsentlig arbejdskraft, er givet.

Per Friis er altså tilsyneladende blevet ramt af svigtende indtægter. Han har måske haft svært ved at opretholde dyrkningen af sin jord på grund af manglende arbejdskraft og har til sidst set sig nødsaget til at pantsætte sit gods for at klare sine forpligtelser som herremand, dvs. krigstjeneste under fuld udrustning til gengæld for skattefriheden. Kronen var netop på denne tid villig til at træde til især i hertugdømmet, hvor Valdemar Atterdag søgte at begrænse de holstenske grevers indflydelse, bl. a. ved godserhvervelser. Pantebrevet fandtes tilsyneladende senere i kronens arkiv, og det er vel derfor næppe nogensinde blevet indløst af Per Friis eller hans arvtagere.

Spørgsmålet er dog, om dette gods forblev ved kronen; man bemærker, at der tales om »den gård Hejsager «, hvilket peger hen på den gård, der i 1500-tallet benævnes „Hejsagergård «. Der behøver naturligvis ikke at være tale om den samme gård, men Hejsagergård ejedes i 1500-tallet af slægten Emmiksen, og man kan 
derfor formode, at Per Friis' gods er kommet til Limbek'erne efter kong Valdemars død, da hans efterfølger, dronning Margrethe, i hvert fald for en tid opgav forsøget på at vinde fodfæste i hertugdømmet Slesvig og tilbagevinde det til kongeriget. Derefter er det kommet til slægten Emmiksen.

På samme måde, som det gik med Per Friis' gods, er det formodentlig gået med andre småherremænds gods. $\mathrm{Da}$ de ikke længere så sig istand til at opretholde besiddelsen af det, er det blevet erhvervet af Limbek'erne, der var de eneste i denne egn, der har været interesseret $\mathrm{i}$ deres gods og har kunnet bære krisens virkninger. Vi må som nævnt formode, at det $i$ hvert fald er sket for Bolet, Vonsmose og Kingsgårds vedkommende. I afsnittet nedenfor, "Slægten Røvers fallit", skal det vises, hvorledes vi kan forestille os, at denne proces er foregået, selvom det her er kapitlet $i$ Haderslev og ikke Limbek'erne, der erhvervede godset.

\section{Overgang til senmiddelalderens godssystem}

Endnu en ting falder $\mathrm{i}$ øjnene ved betragtning af det betydelige gods, som Limbek'erne tilsyneladende har ejet på Næsset omkring år 1400. Der er ovenfor fremsat den formodning, at Godske Tedinghusen og Otto Limbek har siddet som Limbek'ernes fogeder på hhv. Vonsmose og Kingsgård i Kelstrup. Også Esbern Tagesen og Emmike Esbernsen har måske oprindeligt været fogeder for Limbek'erne, før de - formodentlig ved ægteskab kom i varig besiddelse af et omfattende gods på Næsset. ${ }^{64}$

Det spørgsmål rejser sig derfor, hvorfor der har været brug for sådanne fogeder $i$ et område, der ikke ligger særligt langt fra Tørning (afstanden fra Tørning til Årøsund er i luftlinje kun ca. 20 $\mathrm{km}$ ). Spørgsmålet må nok besvares i lyset af det, der her er sagt om det perspektiv, som gennemgangen af de enkelte slægter åbenbarer. $\mathrm{Vi}$ aner som nævnt, at meget gods på forskellig vis er vandret fra mindre herremænd til Limbek'erne på Tørning, og samtidig aner vi, at dette gods havde en anden struktur end den, vi kender i $1400-$ og 1500-tallet. Per Friis og hans gods er et eksempel på de problemer, som disse herremænd stod overfor. Men problemet med at få jorden dyrket og gården besat var vel ikke overvundet, selvom en godsejer med større fysisk magt end den lille herremand 


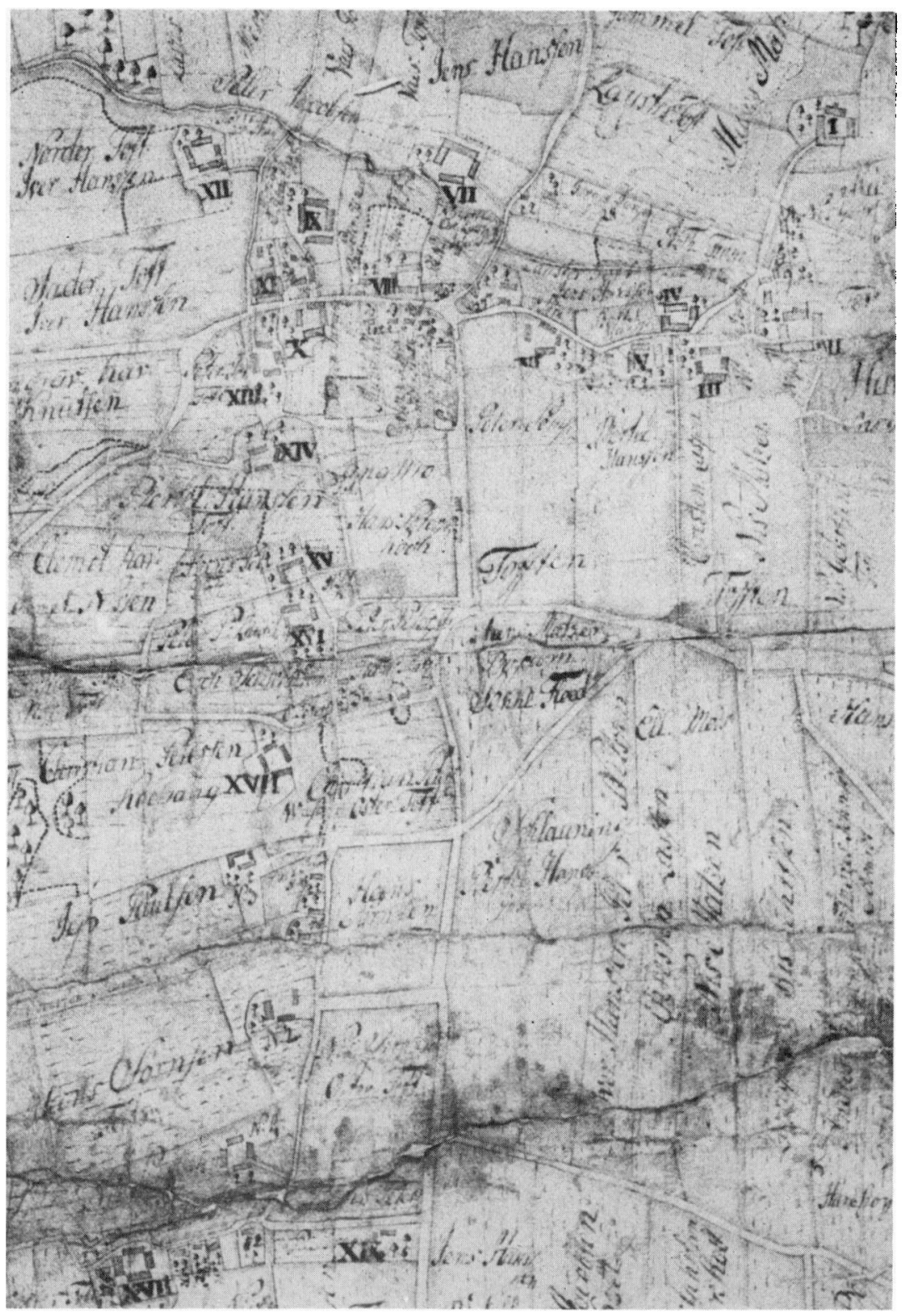


nok har kunnet tvinge de små jorddyrkere til at blive på gårdene og dyrke jorden. Vanskelighederne ved at få jorden dyrket har betydet, at også Limbek'erne har haft brug for mænd, de kunne stole på, til at føre kontrol med, at ingen forlod jorden, til at forestå den eventuelle omfordeling af jorden, der måtte til, således at de mindre fæstere fik mere jord, og det kunne blive mere tillokkende at træde i fæsteforhold til jorddrotten. Derfor er disse lavadelige, til dels af fremmed herkomst, rykket ind på de befæstede gårde - de nuværende voldsteder - hvor de tidligere småherremænd havde siddet. Herfra har de kunnet holde et vågent øje med, at alt forløb som det skulle i den omstruktureringssproces, som vi må forestille os er sket $\mathrm{i}$ årtierne omkring 1400. Som løn for deres indsats har de fået overdraget indtægter af en række gårde og jorder, ja noget har de måske fået overdraget som ejendom, og de har samtidig fået mulighed for selv at erhverve sig gods. Først da denne proces var tilendebragt, og der var skabt en struktur, hvor brugene var af mere ensartet størrelse end tidligere, er disse fogedembeder blevet inddraget og befæstningerne på de tidligere herremandsgårde blevet opgivet eller sløjfet.

Den struktur, som vi kender i dag på Næsset, med pæne gårde af en rimelig størrelse skulle således ifølge det, der her er sagt, først være skabt i løbet af første halvdel af 1400-tallet. Denne proces danner således en voldsom barriere for forståelsen af strukturen $\mathrm{i}$ 1300-tallet og længere tilbage i tiden. Kun i glimt får vi lejlighed til at kaste et blik over barrieren. Meget er skjult for os og meget må vi gætte os til på grundlag af de glimt, vi får at se. Det er det, der er forsøgt her.

Landsbyen Hejsager, et eksempel på senmiddelalderens andrede forbold

Et udmærket indtryk af omstruktureringsprocessen i senmiddelalderen får vi gennem et studium af ejendomsforholdene i Hejsager,

Udsnit af udskiftningskort over Halk sogn 1790, visende landsbyen Hejsager. Gärdene er nummereret med romertal I-XIX, begyndende med I øverst til bøjre og med XIX nederst. Nordligst $i$ landsbyen, syd om nr. VII, nord om nr. IV og syd om $n r$. II snor den bak sig, som landsbyen er opstået omkring. Kortets vejnet genfindes let $i$ landsbyen idag. (Landsarkivet $i$ Ábenrä) 
hvor ifølge oversigten $\mathrm{i}$ tabel 3 ialt 11 gårde skulle have hørt under Tørning. Der er bevaret et udskiftningskort over hele Halk sogn fra $1790^{65}$, og ved at følge de enkelte ejendomme tilbage gennem tiden på grundlag af jordebøger og regnskaber er det muligt at få indtryk af ejendommenes beliggenhed $\mathrm{i}$ hvert fald ved middelalderens slutning, dvs. $i$ begyndelsen af 1500-tallet. ${ }^{66}$ Gårdene $i$ Hejsager er på kortet 1790 nummereret fra øst til vest (nr. I-XII) og derefter fra nord imod syd (nr. XIII-XIX). Blandt disse sidste, der er beliggende næsten på linje syd for den oprindelige landsby, er der formodentlig tale om en del udflyttergårde. Det er klart, at disse i nogen grad gør det vanskeligt at fà et helt præcist billede af samtlige gårdes beliggenhed ved middelalderens slutning, men disse gårde er formodentlig flyttet fra den midterste del af landsbyen, hvor der synes at være et hul i rækken af gårde.

Gård nr. I, østligst i landsbyen, er Gammelbykær. ${ }^{67}$ Der er altså tale om den gård, som Hans og Peter Røver i 1421 skødede til Haderslev kapitel, som da også var i besiddelse af den ved reformationen. Ud fra dette kan der næppe være tvivl om, at voldstedet i Henneskær, som ligger umiddelbart øst for Hejsager og Gammelbykær er slægten Røvers og måske endda må opfattes som ridder Jens Bondesens hjemsted i 1330'erne. Hvor slægten Røvers øvrige gårde i Hejsager var beliggende, er vanskeligt at sige. Også de kom som næunt til kapitlet, men netop kapitlets øvrige gårde i Hejsager hører i 1790 til dem, der er udflyttet (nr. XIV, XV og XVIII). Af kortet 1790 fremgår endvidere, at vangeskellet mellem Hejsager og Sode landsbyer øst for Hejsager slår en mærkelig bue rundt om Henneskær. Der må her utvivlsomt være tale om den tidligere hovedgårds tilliggende jord, som på et tidspunkt i middelalderen er udskilt fra landsbyens jord. Denne jord var i $1790 \mathrm{og}$ formodentlig allerede i 1500-tallet delt mellem en af gårdene i Sode og gård nr. I, dvs. Gammelbykær. ${ }^{68}$

Vender vi os imod den vestlige del af landsbyen, kan gård nr. XII, den vestligste, identificeres som den tidligere Hejsagergård, der tilhørte slægten Emmiksen og dens efterkommere, og som formodentlig også må være identisk med Per Frï' Hejsagergård i 1373.69

I gård nr. IX, der ligger lidt øst for Hejsagergård, indgår selvejerjord, og den oprindelige selvejergård, hvis jord 1790 er delt mellem 
tre gårde, har formodentlig ligget lidt nord for gård nr. IX nord for bækken. Navnene Vasetoft og vest herfor Vestertoft angiver beliggenheden. ${ }^{70}$

Resten af gårdene $\mathrm{i}$ landsbyen er fæstegårde. Nr. II-VI ligger østlig i landsbyen og går bortset fra gård nr. VI, der i 1540 var kronens fæster, alle tilbage til Tørning. Også nr. VII og XI var fæstebønder under kronen i 1540, mens nr. VIII via Tønnes Rantzau går tilbage til Tørning. ${ }^{71}$ Mellem gård VII og VIII lå i 1708 en gård, som i 1790 er forsvundet, og hvis jord da var delt mellem to andre gårde. ${ }^{72}$ Nord og vest for gård nr. VI er der en åben plads, hvor der i 1790 lå en række landbolsteder, men det må formodes, at gård nr. XIII-XIX (evt. kun XV-XIX) oprindelig var beliggende her, før de blev udflyttet i sidste halvdel af 1700-tallet. Blandt de udflyttede gårde er også gård 2-4 (de er på kortet nummereret med arabertal, fordi deres jord ikke er opmålt). Gård 2 og 3 hørte under frigården Bejerholm og nr. 4 under frigården Vestergård.

$\mathrm{På}$ grundlag af denne gennemgang af gårdenes beliggenhed $i$ Hejsager, må vi formode følgende udviklingshistorie for landsbyen som helhed:

600-800 e. Kr. ${ }^{73} \quad$ Landsbyen er opstået omkring vandløbet, der løber fra Grarup sø og imod vest forbi Ultang og ud i Bankel sø. Der har været gårde både nord og syd for bækken. Nord for bækken indicerer bl. a. navnene Vasetoft, Vestertoft, Gammeltoft og Gammelbykær den tidligere bebyggelse.

1200 -tallet

Da en priviligeret krigerklasse i Valdemarstiden udskilles af bondestanden, opstår der i landsbyen to hovedgårde som sæde for to herremandsslægter. Den ene placeres mod øst i Henneskær, hvor dens jord udskilles af landsbyens jord. Denne gård ejes i 1330'erne formodentlig af Jens Bondesen og ca. 1400 af slægten Røver. Til den hører ca. 1400 fem gårde i landsbyen som fæstere. En anden hovedgård anlægges imod 
vest (Hejsagergård), hvor der dog ikke haves arkæologiske vidnesbyrd om noget voldsted. Den ejes ca. 1370 af Per Friis,og til den hørte da fire gårde $\mathrm{i}$ landsbyen som fæstere. Af landsbyens øvrige gårde bliver de fleste efterhånden fæstere under andre herremænd. Der er dog stadig en, måske to selvejergårde tilbage.

Første halvdel af Henneskær forsvinder som hovedgård med 1400-tallet slægten Røvers uddøen og fallit. Dens jord lægges under en fæstegård $i$ Sode og en $i$ Hejsager (Gammelbykær). De fleste gårde i landsbyen, herunder Hejsagergård kommer under Tørning, enkelte kommer under kapitlet i Haderslev. I forbindelse hermed sker formodentlig en omlægning af brugsstørrelserne.

1500-tallet

Tørnings fæstegårde overgår for nogles vedkommende til kronen, mens størstedelen nedarves gennem slægten Emmiksen og dens arvtagere, for ca. 1600 at overgå til kronen. Fra ca. 1600 er alle landsbyens gårde bortset fra selvejeren og Bejerholms to tilliggende gårde, fæstere under kronen eller Vor Frue kirke i Haderslev.

Sidste halvdel af En del gårde $\mathrm{i}$ landsbyens midterste del udflyt1700-tallet tes og placeres på række syd for den vestlige del af landsbyen.

Hvornår gårdene nord for bækken er forsvundet, er vanskeligt at sige. Sandsynligheden taler for, at det kan være sket allerede i middelalderen (ca. 1400), da det bl.a. ud fra Per Frïs' brev må formodes, at der er sket en række omlægninger af gårdene og deres afgifter som følge af agrarkrisen. Det kan også være sket senere, måske i forbindelse med svenskekrigene ved midten af 1600-årene, som betød store ødelæggelser bl. a. på Haderslev Næs. 


\section{Herremand på Nasset ca. 1420}

\section{Sammenfatning}

Af gennemgangen oven for af de forskellige slægter vil det bemærkes, at der især haves mange oplysninger fra tiden omkring 1420. Det er især følgende breve, der giver de mange oplysninger:

1421 2/2 skøder Hans og Peter Røver gods til kapitlet i Haderslev, og der nævnes da 3 vidner;

1422 13/5 bevidnes i Haderslev skødning af gods, og der nævnes da 6 herremænd som vidner;

1422 31/10 skøder Jep Iversen Staverskov Medstedgård til kapitlet i Haderslev, hvilket bevidnes af 5 herremænd.

Disse breve giver oplysning om 10 herremænd bosiddende på Næsset, hvortil kommer 3, der ikke kan lokaliseres, samt 1, som formodentlig ikke hører til på Næsset. Disse 10 herremænd er imidlertid ikke alle Næssets herremænd. Et par lidt senere breve giver oplysning om yderligere 8 herremænd, hvoraf 2 må være hjemmehørende på Næsset, 1 står i slægtskabsforhold til den ene af disse, mens 2 ikke kan lokaliseres og 3 ikke er hjemmehørende på Næsset. Der er tale om følgende breve:

1434 28/6 fru Ingerd Hermensdatter (Pennow) får vidne af Haderslev herredsting; blandt vidnerne nævnes 3 væbnere;

1436 2/7 Godske Eriksen og Iver Pedersen (Rosenkrands) skøder gods til kapitlet i Haderslev, hvilket bevidnes af 4 væbnere.

Alle de nævnte breve, bortset fra brevet 1422 13/5 har forbindelse med kapitlet i Haderslev og er derfor nok udstedt i Haderslev. Det var derfor naturligt, at egnens herremænd mødte op, især fordi de fleste af brevene angår deres standsfællers skødning af gods. Det er således bemærkelsesværdigt, at det er de samme personer, der går igen $i$ flere af brevene, en person forekommer således $i$ tre af brevene, mens tre personer forekommer hver $i$ to breve. Selvom vi kan se, at i hvert fald en person mangler, har vi sikkert $i$ disse breve 


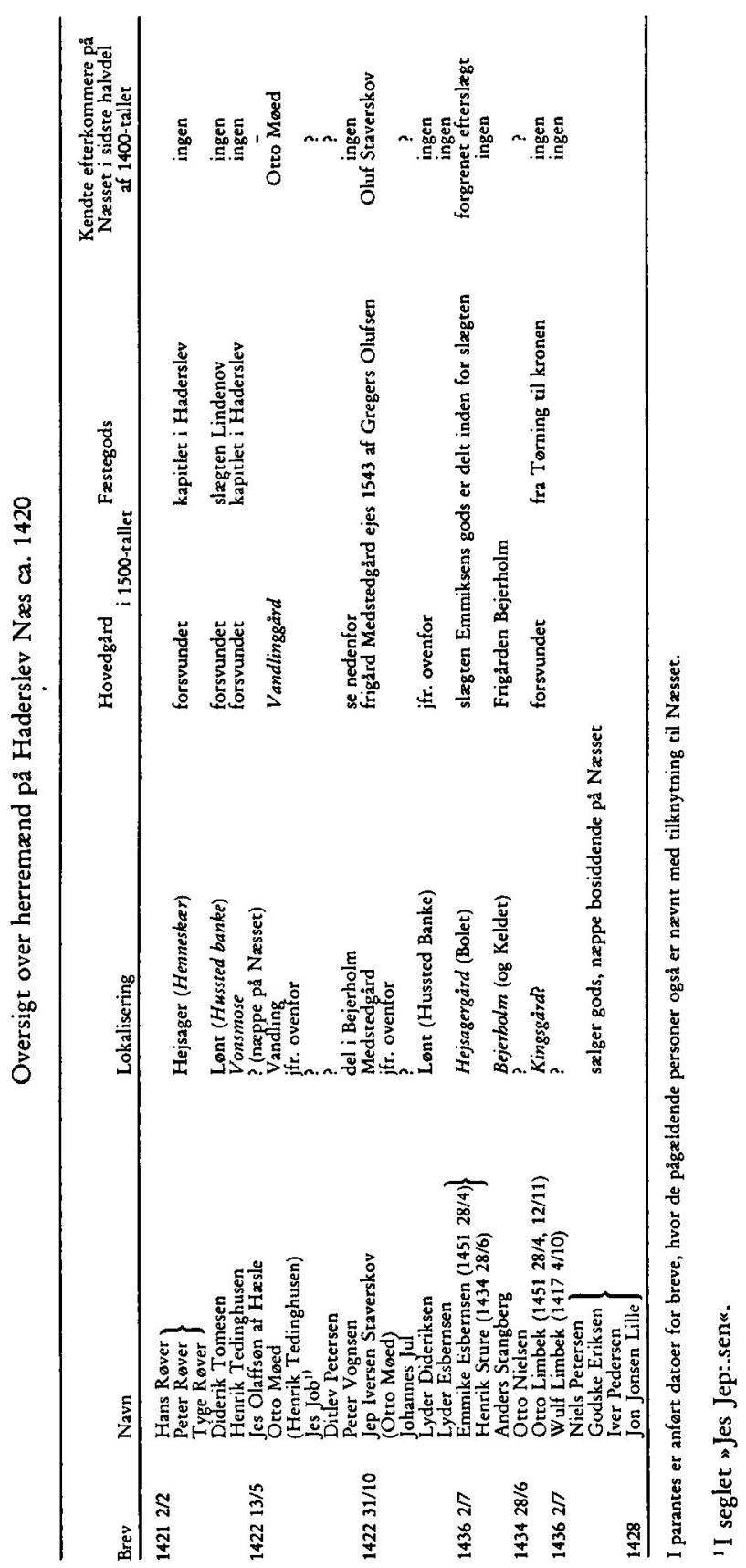


at gøre med langt den største del af de herremænd, der da var hjemmehørende på Næsset.

Oplysningerne $\mathrm{i}$ disse breve om herremænd er på side 40 samlet $\mathrm{i}$ en oversigt, og hertil er knyttet de formodninger, der $\mathrm{i}$ det foregående er fremsat om deres hjemsted. For at illustrere, hvorledes herremændene $\mathrm{i}$ den følgende tid forsvinder, er der endvidere anført de efterkommere, vi kender af dem i slutningen af 1400-tallet, samt hvad der blev af deres gods, såvel hovedgård som fæstegård.

\section{Slagten Røvers fallit}

Langt de fleste af de herremænd, vi kender $i$ begyndelsen af $1400-$ tallet, er altså forsvundet i slutningen af århundredet, og i Hejsager kan der iagttages ret omfattende strukturelle og besiddelsesmæssige forandringer i perioden ca. 1350 til ca. 1450. De to hovedgårde forsvandt, den ene for altid, og de fleste af gårdene i landsbyen kom under Tørning, og samtidig hermed skete der formodentlig en jordfordeling, således at der opstod en række fæstegårde af mere ensartet størrelse under Tørning. Per Friis opgav sit gods ca. 1370, og 50 år senere er vi istand til at følge slægten Røvers fallit. Denne slægt og især dens gods er allerede tidligere omtalt, men en række notitser i diplommaterialet forstås bedre på baggrund af den sammenhæng, som er skitseret ovenfor. De illustrerer samtidig, hvorledes det er gået mange andre små herremandsslægter, der ikke har formået at bære følgerne af krisetilstandene inden for landbruget på denne tid, således som det allerede er bemærket for Per Friis' vedkommende.

1420 2/9 pantsatte Hans Røver til Tord Iversen, borger i Haderslev, for 50 mark lybsk 3 gårde i Hejsager, heriblandt Gammelbygård og Smedegård. Peter og Tyge Røver medbeseglede og billigede altså hermed pantsættelsen. Der var tale om et brugeligt pant, dvs. panthaver fik rådighed over pantet, indtil det blev indløst. Tord Iversen kunne altså disponere over de ind tægter, som Hans Røvers gods gav. Men den sum, Hans Røver herved fik rådighed over, var åbenbart ikke tilstrækkelig for ham. Han har haft brug for flere penge. Et halvt år senere så han og broderen Peter sig nødsaget til at sælge de samme tre gårde, som tidligere var 
pantsat. Salgssummen var $120 \mathrm{~m} . \mathrm{l}$, dvs. betydeligt højere end pantesummen, men af de 120 mark har Hans Røver sikkert måttet udrede de 50 mark til Tord Iversen, således at der kun blev 70 tilbage.

Tord Iversen var imidlertid ikke den eneste, som Hans Røver skyldte penge. Peter og Hans Røver havde tidligere været $\mathrm{i}$ Haderslev for at stampe penge op af jorden, og de havde naturligvis henvendt sig til datidens kapitalbesiddere, kirkens mænd, i dette tilfælde kapitlet ved Vor Frue kirke. Jens Pingesdag, der var kannik, havde da af sine midler lånt brødrene en sum penge mod pant i det gods, som deres fader Niels Røver havde i pant af Jeppe Iversen, nemlig en gård $\mathrm{i} \mathrm{Nr}$. Vilstrup og én $\mathrm{i}$ Halk kaldet Upperkær. Pantesummen udgjorde mindst 20 mark, for da Jens Pingesdag $142322 / 2$ solgte sine rettigheder i dette gods til kapitlet, lod han 20 mark stå i godset. For disse skulle der holdes messe og årtid for ham og hans forældre efter hans død. Kapitlet forundte ham imidlertid at have det pågældende gods »i regnskab“, så længe han boede og levede i Haderslev, og efter hans død skulle hans frænke Christine Jenses »for venskab

Det er ret frie dispositioner, man her træffer med hensyn til gods, som Jens Pingesdag trods alt kun havde i pant. Der kan derfor næppe være tvivl om, at Jens Pingesdags pantebrev aldrig er blevet indløst af Hans og Peter Røver, og godset er endt hos kapitlet som ejendom.

Men slægten Røvers bedrøvelige historie er ikke hermed til ende. Tyve år senere, 1443 4/8, møder vi igen Peter Røver; broderen er nu død, og iøvrigt er der næppe mange medlemmer af slægten tilbage. Som den gudfrygtige og betænksomme mand Peter Røver er, tænker han imidlertid på sin og sine forfædres evige salighed og frelse og indstiftede $i$ den anledning en evig messe, ja mere end det, han stadfæstede den gave, som hans fader Niels gav i form af indstiftelse af »et gejstligt vicarielen« til ære for den hellige Sct. Laurentius. Hertil gav Niels Røver en kalk, en messebog og 40 mark lybsk i sin gård, der til evig tid skulle give 2 mark årlig rente $(=5 \%)$ til den præst, der sad inde med vicariet. Hertil føjede Peter Røver nu to gårde $\mathrm{i}$ Hejsager, kaldet Pugholt, samt al rettighed $\mathrm{i}$ landsbyen Hjerndrup og de rettigheder, som hans afdøde broder Hans, der ikke efterlod sig levende, xgte børn (men altså måske 
uægte?), havde i faderens gård. Herudover skænkede Peter Røver også 20 mark lybsk til hjælp til bygning af et kapel til vicariet. I det tilfælde, at kapellet imidlertid ikke blev bygget, skulle Peter Røver eller hans arvinger have de 20 mark tilbage, dog således at Peter Røvers arvinger eller slægt, så længe der levede nogen heraf, og Henrik Ahlefeldt til Tørning og hans arvinger beholdt retten til at besætte vicariet og forlene det til en præst.

Mærkeligt er det her igen at møde arvtagerne af den slægt, der tilsyneladende $\mathrm{i}$ tidens løb har erhvervet så meget herremandsgods på Haderslev Næs. Har også Peter Røver været afhængig af de mægtige herrer på Tørning, siden Henrik Ahlefeldt er indflettet i dette brev, der næsten har karakter af et testamente? Vi ved det ikke, men det er i hvert fald sidste gang, vi hører noget til slægten. Peter Røver er den sidst kendte repræsentant for slægten, og om han har haft børn vides ikke. Han og slægten forsvinder ud af historien, og vi kan kun gisne om hans videre skæbne. Gik han i en rigere og højerestående herremands sold, blev han landsknægt eller opgav han eller hans efterkommere helt den privilegerede status og blev almindelig bonde? Vi ved det ikke.

Niels, Hans, Peter og Tyge Røver forsvandt og mange andre små herremænd med dem. Andre stod rede til at overtage de værdier, der endnu var tilbage $\mathrm{i}$ form at det gods, de ejede. Men helt forsvundne er disse mænd endnu ikke. Resterne af rammerne om deres daglige liv, voldstederne, ligger der endnu, og voldstedet Henneskær i Halk sogn er måske slægten Røvers hjemsted.

Ingen af disse herremænd rangerede særligt højt på den sociale rangstige. Deres godsgrundlag var så lille, at det næppe gav grundlag for noget særligt overdådigt liv. Der er derfor næppe megen forskel på dem og de privilegerede bønder, som opstod samtidig med, at de sidste småherremænd forsvandt. $141711 / 9^{74}$ havde Erik af Pommern givet Iver Fallesen frihed og frelse for sin gård Medstedgård i Halk sogn, og Jep Iversen Staverskov er måske hans søn. $143027 / 3^{75}$ fik Henrik Ytsen (eller Jytsen) adelsbrev, og hans efterkommere på gården Langmose i Halk sogn sad langt op i tiden inde med særlige privilegier for deres gård. Også andre gårde på Næsset opnåede i den følgende tid privilegier, men der er dog klar forskel på disse privilegier og så de privilegier, som tilhørte herremændene. Deres privilegier, først og fremmest skattefri- 
heden, gik uden videre $i$ arv fra generation til generation og uafhængigt af kongeskifter, mens de privilegier, der hørte til frigårdene, skulle fornys for hver ny ejer af gården, og når der skete et kongeskifte. Frigårdenes ejere kan vel nok betragtes som småherremændenes efterfølgere som det øverste sociale lag inden for de frie bønder, men frigårdenes oprindelse og deres historie er alligevel et helt andet kapitel i Næssets historie, og det vil derfor føre for vidt at berette herom ved denne lejlighed.

\section{NOTER OG HENVISNINGER}

\section{Forkortelser}

DAA $\quad=$ Danmarks Adels Aarbog (1884ff);

Dipl. Dan. = Diplomatarium Danicum, udgivet af Det danske Sprog- og Litteratur selskab, 2. og 3. række;

Kr.Sk. I = Kronens Skøder paa afhændet og erhvervet Jordegods i Danmark, bd. 1 udg. ved L. Laursen, Kbh. 1892;

Rep. Iog II = Repertorium diplomaticum regni Danici mediaevalis, 1.rk., bd. 1-4, udg. ved Kr. Erslev (1894-1912), 2 rk. bd. 1-9, udg. ved William Christensen (1928-39);

Sk. og Jb. = Sønderjyske Skatte- og Jordebøger fra Reformationstiden, udg. ved F. Falkenstjerne og Anna Hude, Kbh. 1895-99.

1. Se især Erik Ulsig: Danske adelsgodser i middelalderen. Kbh. 1968, s. 198-203.

2. Oplysningerne er hentet fra Haderslev Museums sogneregistratur samt fra en registrering foretaget af Olaf Olsen 1968, og hvoraf afskrift haves på Haderslev Museum,jfr. også oversigten i Fra Gelsbro til Lillebælt. Haderslev 1956, s. 52-56.

3. Stedet kaldes også Herrenskær, men Sønderjyske Stednavne. Haderslev Amt. Kbh. 1942, s. 132 anfører, at Henneskær er det oprindelige.

4. RA. Håndskriftsamlingen. Matthiessens samlinger 14 (efter de Vossiske excerpter).

5. Hvor intet andet er anført, er de i det følgende benyttede breve trykt i Aarsberetninger fra det kongelige Geheimerarchiv bd. 2, Kbh. 1856, tillæg "Diplomatarium Collegii Cannonicorum Hadersleviensium. Aktstykker til Oplysning om Kannikecollegiet i Haderslev før Reformationen«, samlede af C. M. A. Matthiessen.

6. Rep. I, nr. 5862 .

7. Rep. I, nr. 5673.

8. Dipl. Dan. II, 12 nr. 186.

9. K. Barner: Familien Rosenkrantz' historie, bd. 1 Kbh. 1874, Diplomatarium nr. 63 s.61, Rep. I, nr. 6964.

10. Rep. II nr. 691,699 og 1552.

11. DAA 1918 s. 432.

12. Sk. og Jb. s. 37 .

13. Se min afhandling "Et forsvundet herresæde i Fjelstrup sogn« i Haderslev Amts Museum bd. 13 s. 83-90.

14. Rep. 1, nr. 5968, Danske Magazin 5 rk. bd. 2, s. $96 \mathrm{f}$.

15. A. Thiset: Danske adelige Sigiller fra det 15., 16. og 17 aarh., 1905, nr. Ixxii 46. 
16. Rep. I, nr. 5026.

17. Rep. I, nr. 5008.

18. Rep. I, nr. 6733.

19. De ældste danske Archivregistraturer bd. 3, s. 278. De kan være inddraget af kronen i forbindelse med reformationen, således at de omfattes af de gårde, der nævnes $i$ Hejsager under kronen 1540, Sk. og Jb. s. 15 og 35.

20. Sk. og Jb. s. 420.

21. Gården i Sode med Langmose og Beyerholm. Udført af P. K. Hofmansen 1951, s. 63 (duplik.) med henvisning til RA. Rentekammeret G. 48 Generallandundersøgelseskommissionen i Slesvig og Holsten 1723-30. Akter vedr. Frigaarde og andre priviligerede Ejendomme i Haderslev Amt 1694-1730.

22. Rep. I, nr. 5862.

23. Gården i Sode s. 84.

24. Gården i Sode s. 85.

25. Sønderjysk Månedsskrift 18. årg. 1942 s. 152, jfr. bemærkningerne om dateringen $\mathrm{i}$ Regesta diplomatica historiae Danicae 1. rk. nr. 3024.

26. Gården i Sode s. 51.

27. Kr. Sk. I.

28. Sk. og Jb. s. 432.

29. Sønderjyske Årbøger 1972 s. 23-24 med note 32 s. 57.

30. Rep. I, nr. 3564, 3846; Udvalg af hidtil utrykte Danske Diplomer og Breve fra det XIVde, XVde og XVIde Aarhundrede, udg. af C. Molbech og N. M. Petersen (1858), nr. 212, s. 337; Antislesvigholstenske Fragmenter, 1848-51, bd. 13, s. 118; Rep. I, nr. 7425.

31. Sk. og Jb. s. 75.

32. DAA 1940 s. 75

33. DAA 1940 s. 76.

34. Rep. I, nr. 5968.

35. Sønderjyske Årbøger 1972 s. 11; Sk. og Jb. s. $418 f$.

36. J. P. Trap: Danmark 5. udg. bd. 10 s. 221.

37. RA Håndskriftsamlingen. Matthiessens Samlinger pk. 14 (efter de Vossiske excerpter).

38. Danmarks gamle købstadlovgivning, bd. 1 Sønderjylland. Kbh. 1951, s. 276.

39. Rep. I, nr. 3491, 4102 og 6901.

40. se note 37.

41. J. P. Trap: Danmark 5. udg. bd. 10, s. 231.

42. Kr. Sk. I.

43. Sk. og Jb. s. 76 .

44. DAA 1902, s. 270.

45. Oplysningerne om disse personer, se DAA 1930 s. $25 \mathrm{f}$ og 1950 s. 40f, slægten Ahlefeldt desuden L. Bobé: Slægten Ahlefeldts historie bd. 2, s. 155; skøderne: Kr. Sk. I.

46. Quellensammlung der Gesellschaft für Schleswig-Holsteinische Geschichte, bd. 6, s. 350-53.

47. RA. Lensregnskaber og jordebøger. Haderslevhus lens jordebog 1596-97.

48. Zeitschrift der Gesellschaft für Schleswig-Holstein-Lauenburgische Geschichte, bd. 4 1873, s. 187 og 188.

49. Sk. og Jb. s. 432.

50. Sønderjyske Årbøger 1972 s. $23 f$.

51. Povl Breide nævnes i Sejdelin: Diplomatarium Flensborgense, bd. 2, Kbh. 1873 s. 470 blandt arvingerne efter Henneke v. $d$. Wisch på sin hustrus vegne.

52. Sejdelin: Diplomatarium Flensborgense bd. 2, Kbh. 1873, s. 30. 
53. 1461 er gårdene kendt, men 1446 kan de beregnes, idet de gårde i Tyrstrup herred, som vi kender under Haderslev kapitel senerehen, men hvor der ikke er bevaret adkomstbreve, må stamme fra den store donation, ejerne af Tørning foretog $i$ dette år.

54. Ultanggård er vanskelig at placere ind $\mathrm{i}$ det her skitserede billede. Gården viser som nævnt rester af et firesidet anlæg, og er 1543 opført som tidligere Tørning-gods (Sk. og Jb. s. 75). Ifølge De ældste danske Archivregistraturer bd. 4 s. 389 fandtes blandt brevene på Tørning wett købebreff af Mester Claus Daa paa en partt i Ultang gordt og mølle«. Mester Claus Daa må være identisk med den Claus Daa, der ca. 1500 var kannik i Roskilde (DAA 1944 s. 26). Hans farfar Christiern Daa havde gods i Sønderjylland og var ifølge en slægtebogsnotits gift med en Rantzau eller en Rønnow (begge slægter førte et delt skjold) (DAA 1944 s. 7). Den eneste tænkelige forklaring på Daa'ernes adkomst til Ultanggård, er derfor, at Ultanggård og mølle oprindelig har tilhørt Rønnow'erne på Ejsbøl, som formodentlig ejede andet gods på Haderslev Næs, jfr. gennemgangen ovenfor (afsnitter Senere opståede hovedgårde).

55. Dipl. Dan. II, $12 \mathrm{nr} .186$.

56. Sk. og Jb. s. 74-77.

57. Disse tal må imidlertid på ingen måde betragtes som et eksakt udtryk for hvad Limbek'erne har ejet på Næsset ca. 1400. Man må her tage i betragtning at tallene for en stor del bygger på en senere tids oplysninger, dels om Tørnings tilliggende ved overgangen til kronen 1494 (=1543), dels om hvad forskellige grene af slægten Emmiksen eller deres arvtagere ejede i slutningen af 1500-tallet. Hertil kommer den store usikkerhed der knytter sig til de tre hovedgårde Boskov, Kestrup og Vilstrupgård og deres oprindelse. De eksakte tal kan derfor have været anderledes, noget gods kan være kommet til, noget, som vi ikke har kendskab til, kan være afhændet, og noget er måske slet ikke tidligere Tørning-gods. Der skulle dog næppe være tale om de store ændringer. Det var i $1400-$ tallet arven der skabte godskomplekser $\mathrm{i}$ højere grad end køb og salg.

58. Dipl. Dan. III, 4 nr. 2

59. Han ejede 14 ore (= 42 ortug) jord og nævnes flere gange med tilknytning til Brede sogn, Dipl. Dan. II, 9 nr. 462 og III, 2 nr. 188.

60. De ældste danske Archivregistraturer bd. 1 s. 93.

61. Historisk Tidsskrift $11 \mathrm{rk}$. bd. 6 s. 189-92.

62. Samling af Adkomster, Indtægtsangivelser og kirkelige Vedtægter for Ribe Domkapitel og Bispestol (Ribe Oldemoder), udg. af O. Nielsen, Kbh. 1869, s. 76; Dipl. Dan. II, $8 \mathrm{nr}$. 312, III, 2 nr. 191 og 3 nr. 127; Ribe Oldemoder s. 86.

63. Se listen hos Erik Ulsig: Danske adelsgodser $\mathrm{i}$ middelalderen s. 126-29 samt Thomas Riis: Villici og coloni indtil 1340, i Landbohistoriske Studier tilegnede Friedlev Skrubbeltrang, Kbh. 1970 s. 1-20.

64. Limbek'erne har tilsyneladende $i$ ret stor udstrækning benyttet sig af fogeder af lavadelig slægt på de faste borge inden for det betydelige gods- og panteområde, som de besad i Syd-og Sønderjylland. Her er nævnt slægterne Tedinghusen og Emmiksen, men også slægterne Pors af Vranderup samt Godendorp er knyttet til Limbek'erne. Johannes Thomesen (Lindenov) navnes 1376 1/9 (Scriptores Rerum Danicarum bd. 8 (Logumbogen) s. 234). som Henneke Limbeks advocatus (foged) på Riberhus og Christiern Frellesøn (Frille) nævnes 1382 21/2 (Schleswig-Holsteinische Regesten und Urkunden bd. $6 \mathrm{nr} .403$ ) som advocatus et famulus (tjener). Claus Limbek d.y. omtaler 21 7/11 sammen med Emmike Esbernsen Henrik Schelle som sin »knecht (Danske Magazin 5. rk. bd. 2 s. 113).

65. LA. Åbenrå. Udskiftningskort nr. 47.

66. Følgende kilder er benyttet til denne rekonstruktion af ejendommenes ejerforhold 
gennem tiderne: RA Lensregnskaber og jordebøger. Haderslevhus lens jordebøger 1596-97, 1672 og 1706; RA. Rentekammeret. Undersøgelseskommissionen 1708 (Fortegnelse over alle ejendomme samt deres ydelser, afgifter og udsæd); LA Åb. Haderslev $\emptyset$ steramtsstue Hovedbog 1790, og LA Åb. Udskiftningsakter Halk sogn 1790. En kombination af disse kilders angivelser af såvel navne som afgifter giver en meget sikker ejerliste fra ca. 1600 til udskiftningen 1790, hvor gårdenes beliggenhed samtidig kan ses på udskiftningskortet. Også den meget faste rækkefølge, gårdene nævnes $\mathrm{i}$ i såvel jordebøger som hovedbogen 1790 , er en vigtig kilde til identifikation.

67. Hans og Peter Røvers gård kaldes 1421 2/2 Gammelbykær. I LA Åb. Haderslev Provstearkiv, Fortegnelse over indtægter til kirkerne i Haderslev Provsti 1564 (Georg Boyes provstibog) anføres fol. 65a ud for Hans Lassen: Gammelbuiker. Der er endvidere tilføjet Anders Hansen (ny ejer). Anders Hansen genfindes i Haderslevhus lens jordebog 1596-97 og identifikationen af Gammelbykærs placering i landsbyen kan herefter ske ved hjælp af de kilder og den metode der er omtalt $i$ note 66.

68. Hans Matzen Kier, der 1790 ejede Gammelbykær, betaler tillige sammen med Rasmus Thomsen Kier i Sode ud over afgifterne af deres respektive gårde endnu en afgift. I Undersøgelseskommissionens fortegnelse over ejendommene 1708 (jfr. note 66) forekommer denne afgift ikke som afgift af en gård men som afgift af jord, der hører under hhv. Gammelbykær og gården i Sode. Denne afgift kan følges tilbage i hvert fald til jordebogen 1596-97.

69. Navnet Hejsagergård kendes tilsyneladende ikke idag i Hejsager, og der er en vis usikkerhed med hensyn til identifikationen. Gård nr. XII kan ganske klart ud fra den metode, der er omtalt i note 66, identificeres som den Hejsagergård, som Margrethe og Magdalene Emmiksen 1583 30/5 solgte til kronen. Den gård, som Johan Norby 1583 7/7 solgte til kronen, og som kan identificeres som gård nr. II, kaldes i skødet „Hovedgården Hesagger«. De to gårde er altså ikke identiske, men betegnelserne heller ikke, selvom Sønderjyske Stednavne, Haderslev amt s. 119 opfatter det som betegnelser for en og samme gård. Denne usikkerhed i betegnelsen gør identifikationen af Hejsagergård 1583 (gård nr. XII) med Per Friis »den gard Hesagher« 1373 en lille smule usikker.

70. Peter Jacobsen ejede ifølge kortet 1790 disse tofter. Ifølge Haderslev $\varnothing$ steramtsstues Hovedbog 1790 (LA Åb.) havde han foruden gård nr. IX del i en gård der var delt mellem fire bønder og som $i$ jordebøgerne kan identificeres som en selvejergård, der ca. 1700 ejedes af Kristen Jydsen og Knud Jurgensen (jordebog 1706 og undersøgelseskommissionen 1708). - Også andre navne på kortet bl. a. Laustes Toft og Gammeltoft vest for Gammelbykær indicerer en mere omfattende bebyggelse nord for bækken end den nu eksisterende.

71. Kronens gårde ca. 1540 er opregnet i Sk. og Jb. s. 15 og 35. Tønnes Rantzaus skøde til kronen er dateret $158311 / 9$ og trykt i Kr. Sk. I.

72. I Haderslev Østeramtstues hovedbog 1790 (LA Åb.) nxvnes under parcel $11 \mathrm{Nis}$ Geertsen og Christian Lassen med to lige store afgifter. Da hovedbogens rækkefølge af afgifter og dermed gårde svarer nøje til jordebøgerne, blot således at en del af afgifterne (og dermed gårdene) $\mathrm{i}$ hovedbogen er delt mellem flere bønder, som regel $\mathrm{i}$ forholdsmæssigt lige store dele, må der være tale om den gård, som Hans Jydsen sad inde med i 1706, og som viser sig at være en tidligere fæster under Tørning.

73. Det er vanskeligt med sikkerhed at fastslå alderen for landsbyer, hvori indgår -ager, men det er dog givet, at denne landsbytype går tilbage til hedensk tid, Kr. Hald: Vore stednavne, 2. udg., Kbh. 1965, s. 100.

74. Se note 7.

75. Se note 25 . 